\title{
Maintenance threonine requirement and efficiency of its use for accretion of whole-body threonine and protein in Atlantic salmon (Salmo salar L.) fry
}

\author{
Xavier Rollin ${ }^{1}$, Jean-Baptiste Wauters ${ }^{1}$, Noélie Bodin ${ }^{1}$, Yvan Larondelle ${ }^{2}$, Wilfried Ooghe ${ }^{3}$, \\ Bernard Wathelet ${ }^{4}$ and Tarik Abboudi ${ }^{1}$ \\ ${ }^{1}$ Laboratoire de Pisciculture M. Huet, Université catholique de Louvain, Route de Blocry, 2, B-1348 Louvain-la-Neuve, Belgium \\ ${ }^{2}$ Unité de Biochimie de la Nutrition, Université catholique de Louvain, Croix du Sud, 2/8, 1348 Louvain-la-Neuve, Belgium \\ ${ }^{3}$ Laboratorium voor Bromatologie, Universiteit Gent, Harelbekestraat 72, 9000 Gent, Belgium \\ ${ }^{4}$ Unité de Chimie Biologique Industrielle, Faculté universitaire des sciences agronomiques, Passage des Déportés, 2, B-5030 \\ Gembloux, Belgium
}

(Received 26 February 2004 - Revised 7 March 2004 - Accepted 31 March 2005)

\begin{abstract}
Eighteen groups of seventy Atlantic salmon (Salmo salar L.) fry (initial mean body weight $0 \cdot 8$ (SD 0.01) g) were fed on semi-purified diets containing graded levels of L-threonine (Thr) in 15 litres aquaria at a temperature of $14.5 \pm 1{ }^{\circ} \mathrm{C}$. Doses of $\mathrm{Thr}$ represented 1, 31, 41, 51, 62, 72, 83 and $93 \%$ of its ideal level for optimum protein deposition. Indispensable amino acids other than Thr were included in the same proportion (on a $\mathrm{g} / 16 \mathrm{~g}$ $\mathrm{N}$ basis) as in the Atlantic salmon fry whole-body carcass. Following $36 \mathrm{~d}$ of feeding and a $36 \mathrm{~h}$ fast, fry were killed for whole-body protein and amino acid analysis. Weight gain $\left(r^{2} 0.98\right)$, protein accretion $\left(r^{2} 0.97\right)$, and Thr accretion $\left(r^{2} 0.97\right)$ were linear $(P<0.01)$ functions of Thr intake. Slope of the Thr accretion regression line showed that the efficiency of Thr utilisation above maintenance was $76 \%$. At zero Thr intake, fry lost $5.4 \mathrm{mg} \mathrm{Thr} / \mathrm{kg}$ body weight ${ }^{075}$ per $\mathrm{d}$. The Thr maintenance requirement was $7.2 \mathrm{mg} / \mathrm{kg}$ body weight ${ }^{075}$ per $\mathrm{d}$ and the Thr requirement for growth was $66 \mathrm{mg}$ for $1 \mathrm{~g}$ protein deposition. Increasing doses of Thr resulted in increased $(P<0.05)$ concentrations of histidine and lysine, and decreased concentrations of isoleucine in whole-body protein. The maintenance need for Thr represented $13.4 \%$ of the total need for Thr. The data suggest that efficiency of Thr utilisation above maintenance is constant at all levels of Thr intake between 1 and $93 \%$ of the level required for optimum protein deposition.
\end{abstract}

Threonine: Amino acids: Atlantic salmon fry: Maintenance requirement: Growth requirement

Among the main approaches to estimating amino acid (AA) requirements, the factorial approach has recently gained acceptance in fish (Hauler \& Carter, 2001a). The method treats a dietary AA requirement as the sum of its physiological components (D'Mello, 2003a) and requires accurate information on efficiency of AA absorption, maintenance AA requirements, whole-body $\mathrm{AA}$ accretion rates, and efficiency of AA utilisation above maintenance (Edwards et al. 1999). The strength of the approach is that it allows requirements to be estimated for animals differing in their productive state (Fuller, 1994) and thus can be applied to a wide range of conditions (Shearer, 1995). This is viewed as particularly appropriate to fish since the productive state of these animals is very susceptible to vary with water temperature, the performance potential of the populations considered or the age of the animal (Rollin et al. 2003a). However, although there is much information on rates of protein accretion in the fish body, one main limitation in the application of the factorial approach to fish is the paucity of quantitative data concerning the maintenance AA requirements and the efficiency with which AA are utilised in meeting the various components of their requirements (Mambrini \& Kaushik, 1995; Mambrini \& Seudre, 1995; Rodehutscord et al. 1997; Hauler \& Carter, 2001a,b; Fournier et al. 2002).

Two different experimental strategies have been proposed in animals to describe the relationship between the body AA accretion and the AA intake: the so-called 'graded supplementation technique' and the 'diet-dilution procedure' (D'Mello, 2003a,b). The first method involves the addition of graded supplements of the crystalline form of the AA under test to a basal diet deficient in that AA (D'Mello, 1982). The second method is based on the sequential dilution of a high-protein 'summit' diet with an isoenergetic proteinfree mixture (Gous, 1980; Morris et al. 1987). The summit diet is normally formulated to contain a large excess of all indispensable AA (IAA) except the one under test, which is set at a lower level of presumed requirements. Although successive dilutions of the summit diet result in different crude protein concentrations, the AA under test will be first limiting at all levels of dilution and the dietary AA pattern will remain constant throughout the diluted series (D’Mello, 1994a,b).

Abbreviations: AA, amino acid; DAA, dispensable amino acid; IAA, indispensable amino acid; LP, low protein; MBW, metabolic body weight; PF, protein free; Thr, threonine.

* Corresponding author: Dr Xavier Rollin, fax +3210 474991, email rollin@efor.ucl.ac.be 
Both strategies have been used for AA requirement estimations in fish. Using the graded supplementation technique, Rodehutscord et al. (1997) estimated the maintenance requirement of rainbow trout (Oncorhynchus mykiss) for several IAA, through intrapolation of dose-response data to zero growth. According to Hauler \& Carter (2001a), a perceived limitation of this approach has been the inability of dietary crystalline AA to sustain fish growth rates (Cowey \& Luquet, 1983; Tacon \& Cowey, 1985; National Research Council, 1993; Cowey, 1994, 1995; Dabrowski \& Guderley, 2002; Dabrowski et al. 2003). However, this limitation may not affect in the same way all species and all sizes of fish in all conditions. Indeed, Rollin et al. (2003a) recently demonstrated that a crystalline AA mixture with the AA composition of fishmeal protein could replace fishmeal protein without any significant difference in growth rate and $\mathrm{N}$ utilisation efficiency in Atlantic salmon (Salmo salar L.) fry when the dietary AA mixtures were coated with agar and when the fry were accustomed to a crystalline AA-rich diet over a period of 1 month before the experiment. Some other authors used the second approach to estimate the efficiency of utilisation (above maintenance) and the maintenance requirement for lysine (Allen et al. 1998), arginine (Fournier et al. 2002) and sulfur AA (Mambrini \& Kaushik, 1995; Mambrini \& Seudre, 1995) in some fish species. This method means that the use of crystalline AA can be avoided and offers a means of formulation with graded levels of protein-bound AA. However, doubts as to the validity of the diet-dilution technique have been raised for several years in some animals (D'Mello, 1982, $1983,1994 a, b)$ and it is still today a matter of some debate (D'Mello, 2003a,b). For example, the data of Morris et al. (1987) showed that distinct and separate growth responses occured to graded supplements of the limiting AA at each protein level in the diluted series, implying reduced utilisation of the first-limiting AA as dietary crude protein increased (D'Mello, 2003a). Moreover, this method is limited by some technical difficulties in fish, particularly substituting appropriate non-protein energy in a pelleted form (Hauler \& Carter, 2001a). Therefore, since the effect of dietary crude protein on the efficiency of AA utilisation above maintenance is controversial in fish (Rodehutscord \& Pack, 1999) and since AA mixtures can be used effectively in Atlantic salmon fry in some specific conditions (Rollin, 1999; Rollin et al. $2003 a$ ), the first approach was prefered to the second in the present study.

In dose-response experiments, the assumed form of the response often influences the estimation of AA requirements for growth and for maintenance. In fish, the broken line model has been used to estimate most of the requirement values reported within the last 10 years (Wilson, 2003). Curvilinear models have also been applied to either the graded supplementation approach (Rodehutscord et al. 1995a,b, 1997) or the diet-dilution procedure (Mambrini \& Kaushik, 1995; Mambrini, 1996; Fournier et al. 2002), but the broken line method does not generally give a worse fit than the nonlinear models with regard to the standard deviation of the residuals (Rodehutscord et al. 2000; Rollin, 1999). Recently, using the graded supplementation approach, several authors (Rollin, 1999; Hauler \& Carter, 2001b) reported that lysine deposition responded linearly to marginal lysine intake in Atlantic salmon juveniles. Therefore, we used the simple linear regression model for presenting our salmon data in the present study.

The purpose of the present study was to evaluate the efficiency of utilisation (above maintenance) and the maintenance requirement of threonine (Thr) in Atlantic salmon fry. These values were determined by the graded supplementation approach using a linear model, as proposed by Fuller et al. (1989), based on the relationship between Thr intake and Thr or protein gain. Thr and protein depositions were calculated using whole-body $\mathrm{N}$ and AA analysis of fry fed on semi-purified diets in which the absorption efficiency of AA could be assumed to be $100 \%$ (Espe et al. 1992; Espe, 1993). Thr was selected for intensive study because: (1) noticeable differences in Thr requirements have been reported among fish species $(20-50 \mathrm{~g} / \mathrm{kg}$ protein), even in salmonids (20-37 g/kg protein; Wilson, 2002, 2003); (2) it is an important limiting AA for poultry and pigs (Saldana et al. 1994; Kidd et al. 1997), but also in practical fish diets, especially when plant protein sources such as maize or wheat gluten are used to replace substantial amounts of dietary fish meal protein (Tibaldi \& Tulli, 1999); (3) it is an AA whose maintenance requirement has been found to be high (relative to lysine) in swine (Baker et al. 1966; Fuller, 1994), but also in rainbow trout where it has been shown to account for $174 \%$ of the lysine maintenance requirement (Rodehutscord et al. 1997); (4) $\mathrm{Thr}$ is a major component of mucosal mucins (Fuller, 1994), a family of large glycoproteins that are important constituents of the mucus that protects not only the gastrointestinal mucosa, but also the skin and the gills in fish (Hara et al. 1984; Perry \& Laurent, 1993). As mucus is constantly being produced and sloughed in fish, Thr losses from epithelia may have a particular significance in this group of vertebrates. Finally, oxidative pathways of Thr may be specific in fish. In higher vertebrates, Thr oxidation forms mainly glycine $(87 \%$ of $\mathrm{Thr}$ oxidation in rats; $80 \%$ in pigs), which can be then oxidised or contribute to glucose formation (Bird \& Nunn, 1983; Ballèvre et al. 1990). Whether this is also true in fish needs further investigation, but this is one more reason for studying its implication for basal metabolism, and thus its importance in maintenance AA requirements in fish.

\section{Materials and methods}

\section{Experimental diets}

Eight semi-purified diets were formulated (Table 1) to contain graded levels of $\operatorname{Thr}(1,31,41,51,62,72,83$ and $93 \%$ of the optimum Thr requirement for salmon fry protein growth (12.1 g Thr/kg dry diet; Rollin et al. 2003a)), supplied by raw materials and a balanced mixture of purified L-amino acids (Table 2). The AA composition of the diets (Table 3) was based on the AA composition of Atlantic salmon fry whole-body carcass taken as a reference (on a g/16 g N basis) for both IAA and dispensable AA (DAA) composition of the diets and met the IAA requirements of Atlantic salmon fry according to Rollin et al. (2003a). Seven graded levels of L-Thr (between 0 and $7.5 \mathrm{~g} / \mathrm{kg} \mathrm{DM}$ ) were added to the high-protein basal diet to give diets with $3.75,5,6.25$, $7 \cdot 5,8.75,10$ and $11.25 \mathrm{~g}$ Thr/kg DM. The Thr added replaced progressively on an $\mathrm{N}$ basis the crystalline DAA mixture 
Table 1. Composition of the experimental diets used for the determination of maintenance and growth requirements for threonine in Atlantic salmon (Salmo salar L.) fry

\begin{tabular}{|c|c|c|c|}
\hline Diets... & PF & LP & $\mathrm{HP} 1-7^{*}$ \\
\hline \multicolumn{4}{|l|}{ Components (g/kg diet) } \\
\hline Cod meal† & 0 & 0 & 10 \\
\hline L-Amino acid mixture $\ddagger$ & 0 & 138.5 & 268 \\
\hline Wheat gluten§ & 0 & 0 & 115 \\
\hline Gelatine§ & 0 & 0 & 40 \\
\hline Cod liver oil|| & 215 & 215 & 205 \\
\hline Glucose & 240 & 150 & 9 \\
\hline Modified starch** & 240 & 281.5 & 177 \\
\hline Sucrose & 150 & 50 & 20 \\
\hline Soya lecithin†† & 40 & 40 & 40 \\
\hline Vitamin mixł‡ & 10 & 10 & 10 \\
\hline Mineral mix§§ & 65 & 65 & 65 \\
\hline Agar§ & 10 & 10 & 10 \\
\hline Carboxymethylcellulose§ & 20 & 20 & 20 \\
\hline$\alpha$-Cellulose $\S$ & 10 & 20 & 10 \\
\hline \multicolumn{4}{|l|}{ Chemical composition } \\
\hline DM (g/kg diet) & 942 & 820 & 921 \\
\hline$N(g / k g ~ D M)$ & 0.1 & $21 \cdot 8$ & $63 \cdot 6$ \\
\hline Fat (g/kg DM) & 253 & 251 & 251 \\
\hline Ash (g/kg DM) & 53 & 62 & 62 \\
\hline Energy (kJ/g DM) & $21 \cdot 8$ & $21 \cdot 3$ & $22 \cdot 4$ \\
\hline
\end{tabular}

PF, protein-free diet; LP, threonine-free low-protein diet.

${ }^{*} \mathrm{HP} 1$, high-protein diet with threonine level of $3.75 \mathrm{~g} / \mathrm{kg}$ DM; HP2, high-protein diet with threonine level of $5.0 \mathrm{~g} / \mathrm{kg} \mathrm{DM}$; HP3, high-protein diet with threonine level of $6.25 \mathrm{~g} / \mathrm{kg}$ DM; HP4, high-protein diet with threonine level of $7.5 \mathrm{~g} / \mathrm{kg} \mathrm{DM}$; HP5, high-protein diet with threonine level of $8.75 \mathrm{~g} / \mathrm{kg} \mathrm{DM}$; HP6, high-protein diet with threonine level of $10 \mathrm{~g} / \mathrm{kg} \mathrm{DM}$; HP7, high-protein diet with threonine level of $11.25 \mathrm{~g} / \mathrm{kg} \mathrm{DM}$

†Toro Food Division, Rieber \& Søn (Bergen, Norway).

$\ddagger$ For the composition of the L-amino acid mixtures, see Table 2.

§Wheat gluten, Sigma (St Louis, MO, USA) G-5004; gelatine, Sigma G-6144 agar, Sigma A-5306; $\alpha$-cellulose, Sigma C-8002; carboxymethylcellulose, Sigma C-4888.

II Federa, Brussels, Belgium.

I Glucose, Merck (Darmstadt, Germany) 8337.5000; sucrose, Merck 7687.5000.

${ }^{* *}$ Merigum; Amylum SA, Alost, Belgium.

t†Cereal, Beerzel, Belgium.

括 Supplied the following (to provide $\mathrm{g} / \mathrm{kg}$ mixture): retinyl acetate $(516 \mathrm{mg} / \mathrm{g}), 0.67$; ascorbic acid, 120; cholecalciferol $(100 \mathrm{mg} / \mathrm{g}), 0.1$; tocopheryl acetate $(34.2)$, 34.2; phylloquinone, 2.2; thiamin, 5.6; riboflavin, 12; pyridoxine, 4.5; calcium pantothenate, 14.1; p-aminobenzoic acid, 40; vitamin $\mathrm{B}_{12}, 0.03$; niacin, 30; biotin, 0.1 ; choline chloride, 300; folic acid, 1.5; inositol, 50; canthaxanthin, 7; butylated hydroxytoluene, 1.5; butylated hydroxyanisole, 1.5; $\alpha$-cellulose, 323.8.

$\S \S$ Supplied the following (to provide $\mathrm{g} / \mathrm{kg}$ mixture): $\mathrm{CaHPO}_{4} .2 \mathrm{H}_{2} \mathrm{O}, 117.28$; $\mathrm{CaHPO}_{4}, 165.28 ; \mathrm{Ca}(\mathrm{PO} 4)_{2} \mathrm{H} 2 \mathrm{O}, 236.03 ; \mathrm{NaHCO}_{3}, 100.44 ; \mathrm{Na}_{2} \mathrm{SO}_{3}, 0.011 ;$ $\mathrm{KCl}, 108.61 ; \mathrm{NaCl}, 143.49 ; \mathrm{KI}, 0.218 ; \mathrm{MgCl}_{2}, 101.88 ; \mathrm{MnSO}_{4} \cdot \mathrm{H}_{2} \mathrm{O}, 1.75 ;$ $\mathrm{FeSO}_{4} .7 \mathrm{H}_{2} \mathrm{O}, 13.51 ; \mathrm{CuSO}_{4} .5 \mathrm{H}_{2} \mathrm{O}, 0.435 ; \mathrm{ZnSO}_{4} .7 \mathrm{H}_{2} \mathrm{O}, 10.88$.

(except proline) present in the high-protein basal diet (Table 2). However, the IAA:DAA ratio of the diets varied only modestly (47:53 to 49:51). The diets based on the high-protein basal diet were isonitrogenous $(63.6 \mathrm{~g} / \mathrm{kg} \mathrm{DM})$ and their lipid concentration and gross energy content were $251.4 \mathrm{~g} / \mathrm{kg}$ $\mathrm{DM}$ and $22.4 \mathrm{MJ} / \mathrm{kg} \mathrm{DM}$ respectively (Table 1 ). Besides the previous diets, a low-protein diet $(21.8 \mathrm{~g} \mathrm{~N} / \mathrm{kg}$ DM; Table 1) devoid of Thr (Table 3) was fed with crystalline AA as the only N sources (Fournier et al. 2002). Its low protein content assured limited excesses of IAA other than Thr. In the lowprotein diet, IAA other than Thr were included in the same proportion (on a $\mathrm{g} / 16 \mathrm{~g} \mathrm{~N}$ basis) as in the high-protein basal diet to avoid one of these IAA to be first limiting in place of Thr. The eight diets, in which Thr could thus be assumed being first limiting, were used to describe the relationship between Thr intake and protein or Thr gain. Finally, a protein-free diet (PF; $0 \cdot 16 \mathrm{~g} \mathrm{~N} / \mathrm{kg} \mathrm{DM}$; Table 1) was also fed to salmon fry to measure the protein or Thr losses of salmon fry fed a diet devoid of all AA.

The experimental diets were produced as previously reported (Rollin et al. 2003a). In particular, crystalline AA mixtures were coated with $1 \%$ agar, as described by Mambrini \& Kaushik (1994), to delay their digestive absorption and optimise their use for protein accretion. After extrusion, the diets were freeze-dried and stored at $-20^{\circ} \mathrm{C}$ until feeding or analysis.

\section{Animals}

The Atlantic salmon fry used in the present experiment came from a batch of 10000 eyed (embryonic) diploid eggs from a commercial US fast-growing stock (Troutlodge, Inc., Spring Garden, WA, USA) of domestic origin. Fry were reared in our laboratory hatchery (M. Huet Fish Culture Laboratory, Université catholique de Louvain-la-Neuve, Belgium) from eggs to the beginning of the experiment, according to Rollin et al. (2003b). After hatching, salmon fry were fed a Trouvit 000 commercial diet (Trouw France SA, Fontaine-les-Vervins, France) up to age $80 \mathrm{~d}$, followed by Trouvit 00 (Trouw France SA) up to the start of the pre-experimental phase. The experiment was conducted in two consecutive phases: a pre-experimental phase necessary for fish to adapt to a free AA-rich diet and the experiment itself.

The pre-experimental phase consisted of a 3-week period of adjustment by the fry to the high-protein diet rich in crystalline AA $(643 \mathrm{~g} / \mathrm{kg}$ crude protein in the diet) and $\mathrm{Thr}$ $(18.75 \mathrm{~g} / \mathrm{kg}$ DM) according to Rollin et al. (2003a). During this pre-experimental period, the fry (mean initial body weight $\left(\mathrm{W}_{i}\right)$ of $\left.0.41(\mathrm{SD} 0.01) \mathrm{g}\right)$ were kept in a single tank and were continuously fed to a slight excess by an automatic feeder $7 \mathrm{~d}$ per week. The daily mortality rate was always below $0.1 \%$.

After $36 \mathrm{~h}$ of food deprivation, immediately before the experimental phase, the salmon fry were weighed $\left(\mathrm{W}_{i}\right.$ of 0.80 (SD 0.01) g) and randomly distributed amongst eighteen indoor aquaria $(0.40 \times 0.24 \times 0.20 \mathrm{~m})$ of 15 litres (seventy individuals per aquarium). Each test diet was randomly allocated to aquaria (two aquaria per diet). Two more aquaria were each filled with seventy fish, which were killed (excess ethylene glycol monophenyl ether) at the beginning of the experiment, and kept frozen $\left(-20^{\circ} \mathrm{C}\right)$ pending the chemical analyses. Biomass density (seventy fish per tank) was in accordance with optimal growth conditions for that species. Water temperature was set near the optimum $\left(14.5 \pm 1^{\circ} \mathrm{C}\right)$. Water quality, water flow rate and light regimen were as previously described (Rollin et al. 2003a). Mortality, if any, was recorded daily. At the end of the $36 \mathrm{~d}$ feeding experimental period, and after $36 \mathrm{~h}$ of food deprivation, the groups were weighed, counted and the individual final mean body weight was calculated. All fish were then killed (excess ethylene glycol monophenyl ether) and kept frozen $\left(-20^{\circ} \mathrm{C}\right)$ for further determination of the final carcass chemical composition.

\section{Feeding}

During the experimental phase, the diets were given manually $6 \mathrm{~d}$ per week two times per d (10.00 and 20.00 hours). Fish 
Table 2. Composition of L-amino acids mixtures ( $\mathrm{g} / \mathrm{kg}$ dry diet) used in the experimental diets*

\begin{tabular}{|c|c|c|c|c|c|c|c|c|}
\hline \multicolumn{9}{|l|}{ Diets... } \\
\hline Threonine level... & LP & HP1 & HP2 & HP3 & HP4 & HP5 & HP6 & HP7 \\
\hline Amino acid $\dagger$ & 0.1 & 3.75 & $5 \cdot 0$ & $6 \cdot 25$ & 7.5 & 8.75 & $10 \cdot 0$ & $11 \cdot 25$ \\
\hline Arginine & $9 \cdot 2$ & $21 \cdot 9$ & 21.9 & $21 \cdot 9$ & 21.9 & 21.9 & 21.9 & $21 \cdot 9$ \\
\hline Histidine & 3.4 & $8 \cdot 4$ & $8 \cdot 4$ & $8 \cdot 4$ & $8 \cdot 4$ & 8.4 & $8 \cdot 4$ & $8 \cdot 4$ \\
\hline Isoleucine & $6 \cdot 3$ & $15 \cdot 4$ & $15 \cdot 4$ & $15 \cdot 4$ & $15 \cdot 4$ & $15 \cdot 4$ & $15 \cdot 4$ & $15 \cdot 4$ \\
\hline Leucine & 10.5 & $24 \cdot 5$ & 24.5 & 24.5 & 24.5 & 24.5 & 24.5 & 24.5 \\
\hline Lysine hydrochloride & $12 \cdot 6$ & $36 \cdot 4$ & $36 \cdot 4$ & $36 \cdot 4$ & $36 \cdot 4$ & $36 \cdot 4$ & $36 \cdot 4$ & $36 \cdot 4$ \\
\hline Methionine & $5 \cdot 1$ & 13.9 & 13.9 & 13.9 & 13.9 & 13.9 & 13.9 & 13.9 \\
\hline Cystine & $1 \cdot 3$ & 1.5 & 1.5 & 1.5 & 1.5 & 1.5 & 1.5 & 1.5 \\
\hline Phenylalanine & $6 \cdot 4$ & $14 \cdot 0$ & $14 \cdot 0$ & $14 \cdot 0$ & $14 \cdot 0$ & $14 \cdot 0$ & $14 \cdot 0$ & $14 \cdot 0$ \\
\hline Tyrosine & 4.9 & $12 \cdot 0$ & $12 \cdot 0$ & $12 \cdot 0$ & $12 \cdot 0$ & $12 \cdot 0$ & $12 \cdot 0$ & $12 \cdot 0$ \\
\hline Threonine & 0 & 0 & $1 \cdot 25$ & 2.5 & 3.75 & $5 \cdot 0$ & $6 \cdot 25$ & 7.5 \\
\hline Tryptophan & $1 \cdot 2$ & 3.9 & 3.9 & 3.9 & 3.9 & 3.9 & 3.9 & 3.9 \\
\hline Valine & 8.2 & $20 \cdot 6$ & $20 \cdot 6$ & $20 \cdot 6$ & $20 \cdot 6$ & $20 \cdot 6$ & $20 \cdot 6$ & $20 \cdot 6$ \\
\hline Alanine & $9 \cdot 6$ & $17 \cdot 8$ & $17 \cdot 6$ & $17 \cdot 4$ & $17 \cdot 2$ & $17 \cdot 0$ & $16 \cdot 9$ & $16 \cdot 7$ \\
\hline Aspartic acid & 6.9 & $14 \cdot 4$ & $14 \cdot 4$ & $14 \cdot 3$ & $14 \cdot 1$ & $14 \cdot 0$ & $13 \cdot 8$ & $13 \cdot 7$ \\
\hline Asparagine monohydrate & $8 \cdot 6$ & $18 \cdot 1$ & $17 \cdot 9$ & $17 \cdot 7$ & $17 \cdot 5$ & $17 \cdot 3$ & $17 \cdot 1$ & $16 \cdot 9$ \\
\hline Glutamic acid & $9 \cdot 8$ & $8 \cdot 6$ & 8.5 & $8 \cdot 4$ & $8 \cdot 3$ & $8 \cdot 3$ & $8 \cdot 2$ & $8 \cdot 1$ \\
\hline Glutamine & 9.8 & 8.5 & 8.4 & $8 \cdot 3$ & $8 \cdot 2$ & $8 \cdot 1$ & $8 \cdot 0$ & $8 \cdot 0$ \\
\hline Glycine & $12 \cdot 2$ & $17 \cdot 8$ & $17 \cdot 6$ & $17 \cdot 4$ & $17 \cdot 2$ & $17 \cdot 0$ & $16 \cdot 8$ & $16 \cdot 7$ \\
\hline Proline & $6 \cdot 2$ & 0 & 0 & 0 & 0 & 0 & 0 & 0 \\
\hline Serine & $6 \cdot 2$ & $9 \cdot 9$ & $9 \cdot 8$ & $9 \cdot 7$ & $9 \cdot 6$ & $9 \cdot 5$ & $9 \cdot 4$ & $9 \cdot 3$ \\
\hline Sum & 138 & 268 & 268 & 268 & 268 & 269 & 269 & 269 \\
\hline
\end{tabular}

LP, threonine-free low-protein diet; HP1, high-protein diet with threonine level of $3.75 \mathrm{~g} / \mathrm{kg} \mathrm{DM}$; HP2, high-protein diet with threonine level of $5.0 \mathrm{~g} / \mathrm{kg} \mathrm{DM}$; HP3, high-protein diet with threonine level of $6.25 \mathrm{~g} / \mathrm{kg} \mathrm{DM}$; HP4, high-protein diet with threonine level of $7.5 \mathrm{~g} / \mathrm{kg}$ DM; HP5, high-protein diet with threonine level of $8.75 \mathrm{~g} / \mathrm{kg} \mathrm{DM}$; HP6, high-protein diet with threonine level of $10 \mathrm{~g} / \mathrm{kg}$ DM; HP7, high-protein diet with threonine level of $11.25 \mathrm{~g} / \mathrm{kg}$ DM.

${ }^{*}$ For details of diets and procedures, see Table 1 and p. 235.

†All amino acids were provided by Ajinomoto Ltd, Tokyo, Japan.

Table 3. Amino acid composition of the experimental diets, along with data on requirements for Atlantic salmon (Salmo salar L.) fry according to Rollin et al. (2003a) ( $\mathrm{g} / \mathrm{kg}$ diet)*

\begin{tabular}{|c|c|c|c|c|}
\hline $\begin{array}{l}\text { Diets... } \\
\quad \text { Amino acid }\end{array}$ & PF & LP & HP1-7† & Requirement \\
\hline Arginine & 0.06 & $11 \cdot 2$ & 31.4 & $18 \cdot 2$ \\
\hline Histidine & 0.03 & 3.9 & $11 \cdot 3$ & $6 \cdot 7$ \\
\hline Isoleucine & 0 & $6 \cdot 7$ & $19 \cdot 1$ & $9 \ddagger$ \\
\hline Leucine & 0.05 & $9 \cdot 6$ & $28 \cdot 8$ & $14 \ddagger$ \\
\hline Lysine & 0.07 & 11.9 & 34.5 & $23 \cdot 9$ \\
\hline Methionine & 0 & $5 \cdot 1$ & $16 \cdot 2$ & $15 \cdot 4 \S$ \\
\hline Cystine & 0 & $1 \cdot 2$ & 3.8 & \\
\hline Phenylalanine & 0 & $6 \cdot 8$ & $19 \cdot 8$ & $25 \cdot 1 \|$ \\
\hline Tyrosine & 0 & $5 \cdot 1$ & $16 \cdot 3$ & \\
\hline Threonine & 0.05 & 0.13 & $3 \cdot 9-11 \cdot 6$ & $12 \cdot 1$ \\
\hline Tryptophan & nd & nd & nd & $3 \cdot 3$ \\
\hline Valine & 0.09 & 8.9 & $26 \cdot 0$ & $12 \ddagger$ \\
\hline Alanine & 0.07 & $11 \cdot 0$ & $24 \cdot 2-22 \cdot 8$ & \\
\hline Aspartic acid & 0.13 & $16 \cdot 1$ & $36 \cdot 4-34 \cdot 2$ & \\
\hline Glutamic acid & 0.22 & $23 \cdot 6$ & $64 \cdot 6-60 \cdot 8$ & \\
\hline Glycine & 0.10 & $13 \cdot 6$ & $31 \cdot 8-30 \cdot 0$ & \\
\hline Proline & 0.07 & $6 \cdot 8$ & $17 \cdot 4$ & \\
\hline Serine & 0.09 & $6 \cdot 6$ & $16 \cdot 6-15 \cdot 6$ & \\
\hline
\end{tabular}

PF, protein-free diet; LP, threonine-free low-protein diet; nd, not detectable by analytical method used (see p. 236).

${ }^{*}$ For details of diets and procedures, see Table 1 and p. 235.

†HP1, high-protein diet with threonine level of $3.75 \mathrm{~g} / \mathrm{kg} \mathrm{DM}$; HP2, high-protein diet with threonine level of $5.0 \mathrm{~g} / \mathrm{kg} \mathrm{DM}$; HP3, high-protein diet with threonine level of $6.25 \mathrm{~g} / \mathrm{kg} \mathrm{DM}$; HP4, high-protein diet with threonine level of $7.5 \mathrm{~g} / \mathrm{kg} \mathrm{DM}$; HP5, high-protein diet with threonine level of $8.75 \mathrm{~g} / \mathrm{kg} \mathrm{DM}$; HP6, high-protein diet with threonine level of $10 \mathrm{~g} / \mathrm{kg} \mathrm{DM} ; \mathrm{HP7}$, high-protein diet with threonine level of $11.25 \mathrm{~g} / \mathrm{kg}$ DM.

$\ddagger$ According to National Research Council (1993).

$\S$ Methionine + cystine.

|l Phenylalanine + tyrosine. were fed to apparent satiation and feed intake was recorded after each meal.

\section{Sampling and chemical analysis}

Initial and final fish carcasses were freeze-dried (Unitop 400L; Virtis, Gardiner, NY, USA), pulverised (particle diameter $<1 \mathrm{~mm}$ ) and homogenised (Grindomix GM 200; Retsch, Haan, Germany), and finally kept frozen $\left(-20^{\circ} \mathrm{C}\right)$ until analysis.

The diets were analysed for $\mathrm{DM}$, crude protein $(\mathrm{N} \times 6.25)$, crude fat, crude ash and gross energy contents. Moreover, the AA content was measured for diets PF, low protein (LP), HP1 and HP6 (Table 3). Fry were analysed for DM, crude protein, crude ash and AA contents. Proximate analyses of samples were conducted using the following conventional procedures (Association of Official Analytical Chemists, 1995): DM by drying at $105^{\circ} \mathrm{C}$ for $24 \mathrm{~h}$; ash by incineration at $550^{\circ} \mathrm{C}$ for $12 \mathrm{~h}$; crude protein $(\mathrm{N} \times 6 \cdot 25)$ by the Kjeldhal method after acid digestion; crude fat by Soxhlet extraction with diethyl ether. The gross energy of the diets was determined with an IKA-C-400 adiabatic calorimeter (Ika-Werk, Breisgau, Germany). Daily protein gain was calculated on the basis of whole-body $\mathrm{N}$ content multiplied by $6 \cdot 25$. The AA analysis of diets and fish samples was carried out using a Biotronik LC3000 AA analyser. The technique is based on the separation of the AA using cation exchange chromatography (using five lithium acetate buffer solutions of increasing $\mathrm{pH}$ and ionic strength) followed by the ninhydrin colour reaction and photometric detection at $570 \mathrm{~nm}$ for the $\alpha$-AA and at $440 \mathrm{~nm}$ for the imino acids (Ooghe, 1983). Samples were 
hydrolysed by boiling $500 \mathrm{mg}$ homogeneous sample in $370 \mathrm{ml}$ azeotropic $6 \mathrm{M}-\mathrm{HCl}$ for $20 \mathrm{~h}$ under reflux and under a continuous $\mathrm{N}$ flow. The hydrolysate was made up to $500 \mathrm{ml}$ and filtered through a sintered glass filter. A sample of the filtrate was evaporated to dryness at $40^{\circ} \mathrm{C}$ in a rotavapor system (Büchi Rotavapor R-114; Flawil, Switzerland). A lithium acetate injection buffer solution of $\mathrm{pH} 2.2(25 \mathrm{ml})$ was added to redissolve the residue. After ultrafiltration $(0.22 \mu \mathrm{m}), 50 \mu \mathrm{l}$ of sample was injected into the analyser. Tryptophan cannot be measured with this procedure.

\section{Calculations}

The following criteria were used to evaluate fish feed intake and nutrient utilisation:

$$
\begin{gathered}
\text { Feed efficiency }=\frac{\left(W_{f}-W_{i}\right)}{D_{i}} \times \frac{1}{2}\left(n_{f}+n_{i}\right) \\
\text { Live-weight gain }(\mathrm{g} / \text { fish })=W_{f}-W_{i} \\
\text { Feed intake }(\mathrm{g} \mathrm{DM} / \text { fish })=\frac{D_{i}}{\frac{1}{2}\left(n_{f}+n_{i}\right)} \\
\text { Protein efficiency ratio }=\frac{\left(W_{f}-W_{i}\right)}{D_{i} \times N_{d} \times 6 \cdot 25} \times \frac{1}{2}\left(n_{f}+n_{i}\right) \times 100 \\
\text { Protein accretion }(\mathrm{g} / \text { fish })=\left(W_{f} \times N_{f} \times 6 \cdot 25-W_{i} \times N_{i} \times 6 \cdot 25\right) \\
\text { Thr gain }(\mathrm{g} \text { Thr } / \text { fish })=\left(W_{f} \times N_{f} \times \mathrm{N}_{f} \times 6 \cdot 25[T h r]_{f}-W_{i}\right. \\
\end{gathered}
$$

where $W_{f}$ and $W_{i}$ are the mean final and initial individual fresh body weights $(\mathrm{g}), D_{i}$, the dry diet intake per aquarium during the experimental period (g DM), $n_{f}$ and $n_{i}$, the number of fish per aquarium at the end and at the beginning of the experiment, $N_{f}$ and $N_{i}$, the $\mathrm{N}$ contents of the whole-body fish at the end and at the beginning of the experimental period (g N/g), and $T h r_{f}$ and $T h r_{i}$, the Thr contents of the whole-body fish at the end and at the beginning of the experiment (g/g AA).

\section{Data analysis}

All data were analysed by one-way ANOVA. Significant differences between treatments were tested using Tukey's multiple range test and values of $P<0.05$ were deemed statistically significant. Four linear-regression equations were determined: Thr and protein $(\mathrm{N} \times 6.25)$ gain $v$. Thr intake, live weight gain $v$. Thr intake, and Thr gain $v$. protein gain; the last-mentioned was used to determine whether the protein accreted contained a constant amount of Thr and whether zero protein gain resulted in zero Thr gain (Edwards et al. 1997). Standard errors were computed for each regression coefficient. Durbin-Watson values were computed for each of the regression equations to prove lack of autocorrelation among data points (Durbin \& Watson, 1951; Draper \& Smith, 1981). The Thr requirement for maintenance (zero Thr or protein gain) was calculated by determining Thr intake at zero gain. All statistics were performed as described in Sokal \& Rohlf (1995), using a Systat statistical package (version 5.2; Systat Inc., Evanston, IL, USA).

\section{Results}

Mortality was very low $(<1 \%)$, was unaffected by dietary treatments and no external pathological signs were observed even in fish fed the low-Thr diet. Final body weight, daily weight gain, feed efficiency (wet weight gain/dry feed intake) and protein efficiency ratio (wet weight gain/protein intake) increased linearly $(P<0 \cdot 01)$ with an increase in dietary Thr level (Table 4). Suppression of Thr in the LP diet led to a significant reduction of body-weight gain and negative values for feed efficiency and protein efficiency ratio.

All dosing data points (1 (obtained with the LP diet), 31, 41, $51,62,72,83$ and $93 \%$ of the ideal Thr level) produced an excellent description of the linear regression of Thr and protein gain $v$. Thr intake (Table 5; Fig. 1). Diet and Thr intakes increased linearly $(P<0.01)$ as dietary $\mathrm{Thr}$ levels increased from 1 to $93 \%$ of ideal levels (Table 5). The correlation of gain $(y ; \mathrm{mg} / \mathrm{kg}$ metabolic body weight (MBW) per d) $v$. Thr intake $(x ; \mathrm{mg} / \mathrm{kg}$ MBW per $\mathrm{d})$ was well described $\left(r^{2} 0.97\right)$ by a linear relationship: $y=-5.44+(0.76$ (SE 0.03) $x)(n$ 16; Fig. 1 (a)). The slope value from the best-fit linearregression equation showed that the efficiency of Thr utilisation above maintenance was 76 (SE 3) \%. Protein gain ( $y$; $\mathrm{mg} / \mathrm{kg}$ MBW per d) as a function of Thr intake $(x ; \mathrm{mg} / \mathrm{kg}$ MBW per d) was also well described $\left(r^{2} 0.97\right)$ by a straight-line fit: $y=-91.1+(15.2(\operatorname{SE} 0 \cdot 7) x)(n$ 16; Fig. 1 (b)). The inverse value of the slope from the best-fit linearregression equation indicated that $66 \mathrm{mg}$ Thr intake is required for $1 \mathrm{~g}$ protein deposition in salmon fry. Extrapolating the linear-regression equations of $\mathrm{Thr}$ and protein gain to the $y$ intercept showed that zero Thr intake resulted in a net daily loss of $5.4 \mathrm{mg}$ whole-body $\mathrm{Thr}$ and $91 \mathrm{mg}$ whole-body protein per $\mathrm{kg} \mathrm{MBW}$. These values are not significantly different $(P>0.05)$ compared with the losses observed in salmon fry fed the PF diet $(4.9 \mathrm{mg}$ whole-body $\mathrm{Thr}$ and $97 \mathrm{mg}$ wholebody protein per $\mathrm{kg} \mathrm{MBW}$ ). Daily $\mathrm{Thr}$ intake required for maintenance was calculated to be $7.2 \mathrm{mg} / \mathrm{d}$ per $\mathrm{kg} \mathrm{MBW}$ based on zero Thr accretion and $6 \mathrm{mg} / \mathrm{d}$ per $\mathrm{kg}$ MBW based on zero protein accretion. Finally, from the linear regression between live weight gain $(y ; \mathrm{mg} /$ fish per $\mathrm{d})$ and Thr intake $(x ; \mathrm{mg} / \mathrm{fish}$ per $\mathrm{d})(y=-1.06+(108 \cdot 1(\mathrm{SE} 4.62) x)(n 16)$; $r^{2}$ 0.98), we estimated the overall Thr requirement per $\mathrm{kg}$ live weight gain (inverse value of the slope $\times 1000$ ), i.e. 9.3 (SE 0.4) $\mathrm{g} \mathrm{Thr} / \mathrm{kg}$ live weight gain.

Fig. 2 shows that $\mathrm{Thr}$ gain $(y ; \mathrm{mg} / \mathrm{fish})$ was a straight-line function of protein gain $(x ; \mathrm{g} / \mathrm{fish})$. The linear-regression equation, $y=-0.185+(49.87(\operatorname{SE} 0.48) x)\left(n 16 ; r^{2} 0.999\right)$, showed that for each $1 \mathrm{~g}$ increase in protein gain, $\mathrm{Thr}$ gain increased by $49.9 \mathrm{mg}$. This suggests that $\mathrm{Thr}$ concentration in the whole-body protein accreted was a constant $5 \%$ at all levels of Thr intake. Some IAA tended to increase or decrease in whole-body protein as Thr was incremented (Table 6). The increase was significant $(P<0 \cdot 05)$ for histidine and lysine and the decrease was significant $(P<0 \cdot 05)$ for isoleucine.

\section{Discussion}

The objectives of the present study were to determine: (1) the efficiency of Thr utilisation above maintenance; (2) the Thr maintenance requirement; (3) the effects of dietary $\mathrm{Thr}$ on the AA composition of protein deposited in Atlantic salmon 
Table 4. Mean initial and final body weight, weight gain, feed efficiency (FE; wet weight gain/dry feed intake) and protein efficiency ratio (PER; wet weight gain/protein intake) of Atlantic salmon (Salmo salar L.) fry fed on graded levels of threonine for $36 \mathrm{~d}^{*}$

(Mean values with their standard errors for two groups of seventy fish)

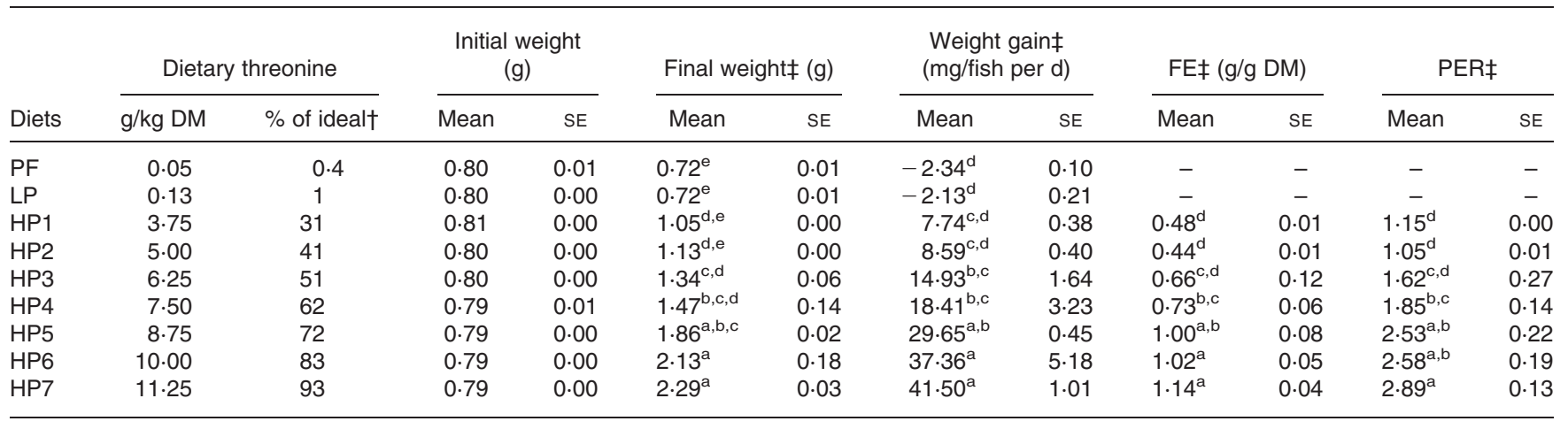

PF, protein-free diet; LP, threonine-free low-protein diet; HP1, high-protein diet with threonine level of $3.75 \mathrm{~g} / \mathrm{kg} \mathrm{DM}$; HP2, high-protein diet with threonine level of $5.0 \mathrm{~g} / \mathrm{kg} \mathrm{DM}$ HP3, high-protein diet with threonine level of $6.25 \mathrm{~g} / \mathrm{kg} \mathrm{DM}$; HP4, high-protein diet with threonine level of $7.5 \mathrm{~g} / \mathrm{kg} \mathrm{DM}$; HP5, high-protein diet with threonine level of $8.75 \mathrm{~g} / \mathrm{kg}$ DM; HP6, high-protein diet with threonine level of $10 \mathrm{~g} / \mathrm{kg} \mathrm{DM}$; HP7, high-protein diet with threonine level of $11.25 \mathrm{~g} / \mathrm{kg} \mathrm{DM}$.

a,b,c,d,e Mean values within a column with unlike superscript letters were significantly different (one-way ANOVA and Tukey's multiple range test; $P>0.05$ ).

${ }^{*}$ For details of diets and procedures, see Table 1 and p. 235.

†Ideal ratio based on Rollin et al. (2003a). All amino acids other than threonine (see Tables 1 to 3 ) were maintained in excess relative to threonine.

$\ddagger$ Linear $(P<0.01)$ response.

fry. To achieve this, we used the approach of feeding graded levels of the limiting AA (Thr), using a linear model, as proposed by Fuller et al. (1989) in pigs or Edwards et al. (1997, 1999) in chicks, based on the relationship between Thr intake and Thr or protein gain. Thr and protein depositions were calculated using whole-body $\mathrm{N}$ and AA analysis of fry fed on semi-purified diets in which the absorption efficiency of AA could be assumed to be $100 \%$ (Espe et al. 1992; Espe, 1993). Except for Thr, the AA profiles in the high-protein diets as well as in the LP diet were chosen in order to simulate the Atlantic salmon whole-body AA composition, including those of DAA. Minor differences in the DAA profiles of diets are due to the fact that progressive suppression of Thr in the diets was compensated by a supply of DAA on an equivalent $\mathrm{N}$ basis. Because the requirement for bioavailable
Thr in Atlantic salmon fry is $12.1 \mathrm{~g} / \mathrm{kg}$ dry diet (Rollin et al. $2003 a$ ), the Thr increments of the present study represented $1,31,41,51,62,72,83$ and $93 \%$ of the ideal level for protein accretion in salmon fry.

There are two common approaches to studying the efficiency of utilising AA for protein or AA accretion: (1) feeding graded levels of the limiting AA in diets containing all other AA at a constant (and excess) level - the 'graded supplementation technique'; or (2) feeding graded levels of an AA mixture (or intact protein) that is first limiting in the AA under study - the 'diet-dilution procedure' (D'Mello, 2003a,b). Both strategies have been used for estimations of fish requirements. In the present study, we used the graded supplementation technique because the effect of dietary crude protein level on the efficiency of AA utilisation above maintenance

Table 5. Accretion of body weight, protein, and threonine in Atlantic salmon (Salmo salar L.) fry fed on graded levels of threonine for $36 \mathrm{~d}^{\star}$ (Mean values with their standard errors for two groups of seventy fish)

\begin{tabular}{|c|c|c|c|c|c|c|c|c|c|c|c|c|}
\hline \multirow[b]{3}{*}{ Diets } & & & \multicolumn{4}{|c|}{ Intake } & \multicolumn{6}{|c|}{ Accretion } \\
\hline & \multicolumn{2}{|c|}{ Dietary threonine } & \multicolumn{2}{|c|}{$\begin{array}{c}\text { Dry dietł } \\
\text { (g DM/fish) }\end{array}$} & \multicolumn{2}{|c|}{$\begin{array}{l}\text { Threonine } \\
\text { (mg/fish) }\end{array}$} & \multicolumn{2}{|c|}{$\begin{array}{l}\text { Body weight } \ddagger \\
\text { (g/fish) }\end{array}$} & \multicolumn{2}{|c|}{ Protein $\ddagger$ (g/fish) } & \multicolumn{2}{|c|}{$\begin{array}{l}\text { Threonine } \\
\text { (mg/fish) }\end{array}$} \\
\hline & Level (g/kg DM) & $\%$ of ideal† & Mean & SE & Mean & SE & Mean & SE & Mean & SE & Mean & SE \\
\hline PF & 0.05 & 0.4 & 0.29 & 0.01 & 0.01 & 0.00 & $-0.08^{d}$ & 0.01 & $-0.016^{d}$ & 0.000 & $-0.80^{d}$ & 0.02 \\
\hline LP & 0.13 & 1 & $0.72^{\mathrm{b}, \mathrm{c}}$ & 0.03 & $0.09^{d}$ & 0.00 & $-0.07^{d}$ & 0.01 & $-0.017^{d}$ & 0.000 & $-0.86^{d}$ & 0.02 \\
\hline HP2 & 5.00 & 41 & $0.74^{\mathrm{b}, \mathrm{c}}$ & 0.01 & $3.69^{c, d}$ & 0.07 & $0.31^{c, d}$ & 0.01 & $0.031^{c, d}$ & 0.001 & $1 \cdot 36^{\mathrm{c}, \mathrm{d}}$ & 0.04 \\
\hline HP3 & $6 \cdot 25$ & 51 & $0.83^{b, c}$ & 0.05 & $5 \cdot 22^{c, d}$ & 0.30 & $0.54^{b, c}$ & 0.06 & $0.058^{\mathrm{c}}$ & 0.008 & $2 \cdot 65^{\mathrm{c}}$ & 0.37 \\
\hline HP4 & $7 \cdot 50$ & 62 & $0.89^{a, b, c}$ & 0.09 & $6 \cdot 67^{b, c, d}$ & 0.67 & $0.66^{b, c}$ & 0.12 & $0.078^{\mathrm{b}, \mathrm{c}}$ & 0.016 & $3 \cdot 64^{b, c}$ & 0.77 \\
\hline HP5 & 8.75 & 72 & $1.07^{\mathrm{a}, \mathrm{b}}$ & 0.07 & $9 \cdot 28^{a, b, c}$ & 0.65 & $1.06^{a, b}$ & 0.02 & $0.134^{a, b}$ & 0.000 & $6 \cdot 46^{a, b}$ & 0.00 \\
\hline HP6 & $10 \cdot 00$ & 83 & $1.29^{a}$ & 0.08 & $12 \cdot 99^{\mathrm{a}, \mathrm{b}}$ & 0.84 & $1 \cdot 34^{\mathrm{a}}$ & 0.19 & $0.170^{a}$ & 0.018 & $8 \cdot 19^{a}$ & 0.87 \\
\hline HP7 & $11 \cdot 25$ & 93 & $1 \cdot 29^{\mathrm{a}}$ & 0.03 & $14 \cdot 53^{\mathrm{a}}$ & 0.30 & $1.50^{\mathrm{a}}$ & 0.04 & $0.192^{a}$ & 0.001 & $9.64^{a}$ & 0.05 \\
\hline
\end{tabular}

PF, protein-free diet; LP, threonine-free low-protein diet; HP1, high-protein diet with threonine level of $3.75 \mathrm{~g} / \mathrm{kg} \mathrm{DM}$; HP2, high-protein diet with threonine level of $5.0 \mathrm{~g} / \mathrm{kg} \mathrm{DM}$; HP3, high-protein diet with threonine level of $6.25 \mathrm{~g} / \mathrm{kg} \mathrm{DM}$; HP4, high-protein diet with threonine level of $7.5 \mathrm{~g} / \mathrm{kg} \mathrm{DM}$; HP5, high-protein diet with threonine level of $8.75 \mathrm{~g} / \mathrm{kg}$ DM; HP6, high-protein diet with threonine level of $10 \mathrm{~g} / \mathrm{kg}$ DM; HP7, high-protein diet with threonine level of $11.25 \mathrm{~g} / \mathrm{kg} \mathrm{DM}$.

$\mathrm{a}, \mathrm{b}, \mathrm{c}, \mathrm{d}, \mathbf{e}$ Mean values within a column with unlike superscript letters were significantly different (one-way ANOVA and Tukey's multiple range test; $P>0.05$ ).

${ }^{*}$ For details of diets and procedures, see Table 1 and p. 235. The initial body weight of the fry was 0.80 (SD 0.01 ) g. The fish were kept at a temperature of $14.5 \pm 1{ }^{\circ} \mathrm{C}$. †ldeal ratio based on Rollin et al. (2003a). All amino acids other than threonine (see Tables 1 to 3 ) were maintained in excess relative to threonine. $\ddagger$ Linear $(P<0.01)$ response. 

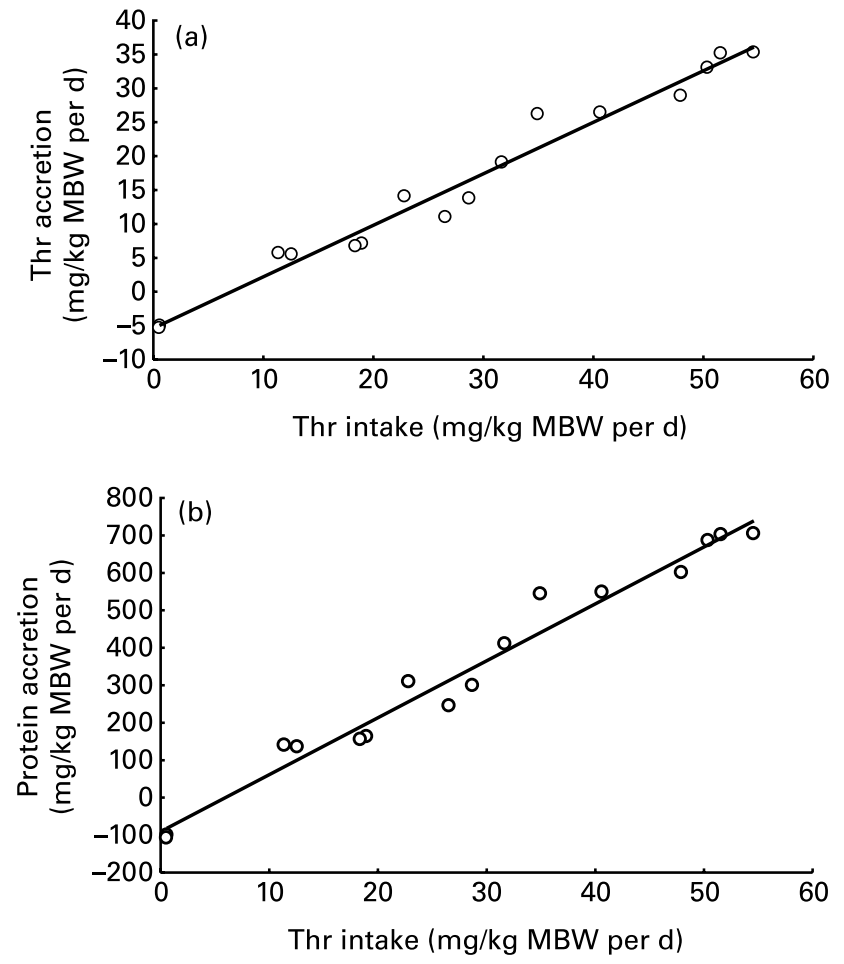

Fig. 1. Best-fit straight-line plots of (a) whole-body threonine (Thr) accretion $(y)$ as a function of Thr intake $\left(x ; y=-5.44+(0.76\right.$ (SE 0.03) $x)(n 16) ; r^{2}$ 0.97 ; Durbin-Watson value $=2.18$ ) and (b) whole-body protein accretion $(y)$ as a function of Thr intake $\left(x ; y=-91.1+(15.2\right.$ (SE 0.7) $x)(n 16) ; r^{2}$ 0.97 ; Durbin-Watson value $=2.22$ ) for Atlantic salmon (Salmo salar L.) fry fed on graded increments of L-Thr. MBW, metabolic body weight ((initial body weight ${ }^{0.75}+$ final body weight $\left.{ }^{0.75}\right) / 2$ ). Each data point represents the mean gain of seventy fish per aquarium during a $36 \mathrm{~d}$ feeding period. For details of diets and procedures, see Tables 1-3 and p. 235 .

is not resolved in fish to date. This raises the question of the validity of the diet-dilution technique in fish. In addition to this 'a contrario' reason, we recently demonstrated (Rollin, 1999; Rollin et al. 2003a) that AA mixtures can be used effectively in Atlantic salmon fry under some specific conditions (AA profile simulating the AA composition of fishmeal protein, AA mixtures coated with agar, accustomisation of fry to a crystalline AA-rich diet, etc). Therefore, the reported inability of dietary crystalline AA to sustain fish growth (Cowey \& Luquet, 1983; National Research Council, 1993; Cowey, 1994; Dabrowski et al. 2003) is no more a limitation in salmon fry and the graded supplementation technique can be performed effectively with this species under these conditions.

In both aforementioned procedures, absolute intake of the limiting AA is a function of both voluntary food intake and concentration of the limiting $\mathrm{AA}$ in the diet (Chung \& Baker, 1992). The estimation of AA requirements for growth and for maintenance depends on the interpretation of this function, and in particular what form of response is assumed (Fuller, 1994). Several non-linear models as well as the linear broken line approach have been suggested for animals (Pack et al. 2003). The question of the model chosen is directly related to the question of whether the efficiency of AA utilisation decreases or remains constant as AA intakes above maintenance increase. Whether diminishing returns

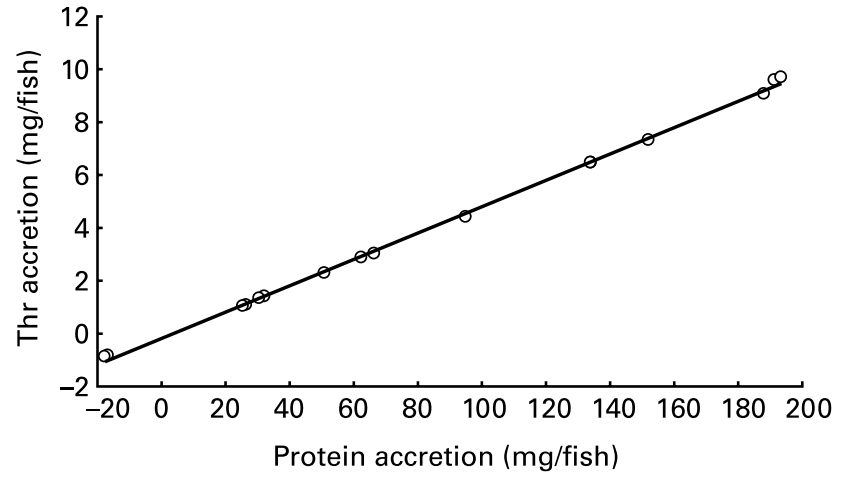

Fig. 2. Best-fit straight-line plots of whole-body threonine (Thr) accretion (y) as a function of protein accretion ( $x$ ) for Atlantic salmon (Salmo salar L.) fry fed on graded increments of L-Thr $(y=-0.185+(49.866$ (SE 0.478) $x)(n 8)$; $r^{2}$ 1.00; Durbin-Watson value $=2$ ). Each data point represents the mean gain of 140 fish during a $36 \mathrm{~d}$ feeding period. For details of diets and procedures, see Tables $1-3$ and p. 235.

occur in AA utilisation as intakes increase above maintenance has been controversial for many years (Fisher et al. 1973; Heger \& Frydrych, 1985; Baker, 1991; Fuller \& Garthwaite, 1993; Gahl et al. 1996; Rodehutscord \& Pack, 1999; Baker, 2003; Pack et al. 2003). Indeed, the differences in curvilinearity seen in published data are striking (Fuller \& Garthwaite, 1993). For example, in mammals and birds, the data of some authors (Campbell et al. 1984, 1985; Dunkin et al. 1986; Fuller et al. 1989; Batterham et al. 1990; Baker, 1991; Chung \& Baker, 1992; Bikker, 1994; Adeola, 1995; Baker et al. 1996; Edwards et al. 1997, 1999) represented very well the responses of their animals by straight lines. Gahl et al. (1991, 1996) and Heger \& Frydrych (1985) interpreted their rat data as suggesting decreasing utilisation of lysine and Thr as graded doses of each AA were increased. However, Baker et al. (1996) studied their response curves carefully and concluded that straight-line fits appeared to describe their response curves as well as curvilinear fits if one eliminates AA intakes near and above the requirement. In fish, most of the requirement values that have been reported within the last 10 years have been estimated, based on the broken line model (Wilson, 2003). Curvilinear models have also been applied to either the graded supplementation approach (Rodehutscord et al. 1995a,b, 1997; Rollin, 1999) or the diet-dilution procedure (Mambrini \& Kaushik, 1995; Mambrini, 1996; Fournier et al. 2002), but the broken-line approach does not generally give a worse fit than the nonlinear models with regard to the standard deviation of the residuals (Rodehutscord \& Pack, 1999; Rollin, 1999; Fournier et al. 2002). Rollin (1999) reported a comparison of regressions according to the four-parameter nutrient kinetics model of Mercer (1982) and the simple linear regression model proposed by Fuller et al. (1989) for describing the relationship between lysine gain and lysine intake in Atlantic salmon fry fed on graded levels of lysine and concluded that the linear model did not give a worst fit than the four-parameter model $\left(r^{2} 0.967\right.$ v. $\left.r^{2} 0.968 ; n 31 ; P>0.05\right)$. Also Hauler \& Carter (2001b) reported that lysine deposition responded linearly to marginal lysine intake in Atlantic salmon parr. In the present study, the linear plots depicted in Fig. 1 resulted in Durbin-Watson values of 2.2, and 
Table 6. Nitrogen content ( $\mathrm{g} / 100 \mathrm{~g}$ fresh fish) and amino acid composition of whole-body protein ( $\mathrm{g} / 100 \mathrm{~g}$ amino acids) in Atlantic salmon (Salmo salar L.) fry fed on different experimental diets containing graded levels of threonine*

(Mean values with their standard errors for two groups of seventy fish)

\begin{tabular}{|c|c|c|c|c|c|c|c|c|c|}
\hline $\begin{array}{l}\text { Diets... } \\
\quad \text { Threonine level... }\end{array}$ & $\begin{array}{l}\mathrm{LP} \\
0 \cdot 13\end{array}$ & $\begin{array}{l}\mathrm{HP} 1 \\
3.75\end{array}$ & $\begin{array}{r}\mathrm{HP} 2 \\
5.0\end{array}$ & $\begin{array}{l}\mathrm{HP3} \\
6 \cdot 25\end{array}$ & $\begin{array}{r}\text { HP4 } \\
7.5\end{array}$ & $\begin{array}{l}\text { HP5 } \\
8.75\end{array}$ & $\begin{array}{l}\text { HP6 } \\
10 \cdot 0\end{array}$ & $\begin{array}{l}\text { HP7 } \\
11 \cdot 25\end{array}$ & SEM \\
\hline $\mathrm{N} \dagger$ & $1.96^{a, b}$ & $1.95^{\mathrm{b}}$ & $1.98^{a, b}$ & $1.97^{a, b}$ & $2 \cdot 02^{a, b}$ & $2 \cdot 06^{a, b}$ & $2 \cdot 07^{a, b}$ & $2 \cdot 08^{a}$ & 0.02 \\
\hline \multicolumn{10}{|l|}{ Amino acids } \\
\hline Arginine & 7.09 & $6 \cdot 81$ & $7 \cdot 13$ & $7 \cdot 17$ & 7.05 & 7.06 & $7 \cdot 11$ & 7.05 & 0.08 \\
\hline Histidine† & $2.39^{b}$ & $2 \cdot 49^{\mathrm{a}, \mathrm{b}}$ & $2 \cdot 51^{a, b}$ & $2 \cdot 53^{a, b}$ & $2 \cdot 54^{a, b}$ & $2.57^{a}$ & $2 \cdot 56^{a, b}$ & $2.59^{a}$ & 0.03 \\
\hline Isoleucine $\ddagger$ & $4.09^{a}$ & $3 \cdot 87^{a, b}$ & $3 \cdot 82^{a, b}$ & $3 \cdot 82^{a, b}$ & $3.41^{\mathrm{b}}$ & $3 \cdot 74^{a, b}$ & $3 \cdot 64^{b}$ & $3 \cdot 78^{a, b}$ & 0.06 \\
\hline Leucine & $7 \cdot 65$ & $7 \cdot 65$ & $7 \cdot 57$ & 7.57 & 7.66 & 7.64 & 7.53 & $7 \cdot 62$ & 0.06 \\
\hline Lysine† & $8 \cdot 53^{b}$ & $8 \cdot 51^{b}$ & $8 \cdot 50^{b}$ & $8 \cdot 61^{a, b}$ & $8.59^{a, b}$ & $8 \cdot 94^{a}$ & $8 \cdot 68^{a, b}$ & $8 \cdot 81^{a}$ & 0.07 \\
\hline Methionine & $3 \cdot 29$ & $3 \cdot 30$ & $3 \cdot 25$ & $3 \cdot 24$ & $3 \cdot 32$ & 3.23 & $3 \cdot 30$ & $3 \cdot 34$ & 0.02 \\
\hline Cystine & 0.59 & 0.38 & 0.36 & 0.44 & 0.41 & 0.42 & 0.37 & 0.43 & 0.07 \\
\hline Phenylalanine & $4 \cdot 25$ & $4 \cdot 15$ & $4 \cdot 20$ & 4.19 & 4.06 & $4 \cdot 19$ & $4 \cdot 13$ & $4 \cdot 19$ & 0.02 \\
\hline Tyrosine & $3 \cdot 31$ & 3.34 & 3.37 & 3.35 & 3.36 & 3.29 & $3 \cdot 30$ & 3.36 & 0.04 \\
\hline Threonine & $4 \cdot 81$ & 4.68 & $4 \cdot 73$ & $4 \cdot 73$ & 4.75 & 4.83 & 4.82 & 4.95 & 0.09 \\
\hline Tryptophan & nd & nd & nd & nd & nd & nd & nd & nd & - \\
\hline Valine & $4 \cdot 61$ & 4.55 & $4 \cdot 14$ & 3.90 & 4.09 & $4 \cdot 11$ & $4 \cdot 32$ & 4.45 & 0.04 \\
\hline Alanine & $6 \cdot 41$ & $6 \cdot 47$ & 6.57 & $6 \cdot 61$ & $6 \cdot 80$ & 6.57 & $6 \cdot 64$ & 6.55 & 0.03 \\
\hline Aspartic acid & 9.87 & 9.96 & $9 \cdot 82$ & 9.90 & $10 \cdot 22$ & $10 \cdot 02$ & $9 \cdot 81$ & $9 \cdot 73$ & 0.02 \\
\hline Glutamic acid & $15 \cdot 37$ & $15 \cdot 61$ & $15 \cdot 29$ & $15 \cdot 33$ & $15 \cdot 85$ & $15 \cdot 45$ & $15 \cdot 17$ & $15 \cdot 00$ & 0.17 \\
\hline Glycine & 7.63 & $7 \cdot 74$ & 8.00 & 8.05 & 8.06 & $7 \cdot 57$ & $7 \cdot 86$ & 7.56 & 0.10 \\
\hline Proline & $4 \cdot 21$ & 4.41 & 4.53 & 4.57 & 4.46 & $4 \cdot 22$ & $4 \cdot 36$ & $4 \cdot 24$ & 0.05 \\
\hline Serine & 4.82 & 4.92 & 4.93 & 4.86 & $5 \cdot 14$ & 4.95 & 4.94 & 4.93 & 0.02 \\
\hline
\end{tabular}

LP, threonine-free low-protein diet; HP1, high-protein diet with threonine level of $3.75 \mathrm{~g} / \mathrm{kg} \mathrm{DM}$; HP2, high-protein diet with threonine level of $5.0 \mathrm{~g} / \mathrm{kg}$ DM; HP3, high-protein diet with threonine level of $6.25 \mathrm{~g} / \mathrm{kg} \mathrm{DM}$; HP4, high-protein diet with threonine level of $7.5 \mathrm{~g} / \mathrm{kg}$ DM; HP5, high-protein diet with threonine level of $8.75 \mathrm{~g} / \mathrm{kg}$ DM; HP6, high-protein diet with threonine level of $10 \mathrm{~g} / \mathrm{kg} \mathrm{DM;} \mathrm{HP7,} \mathrm{high-protein} \mathrm{diet} \mathrm{with} \mathrm{threonine} \mathrm{level} \mathrm{of} 11.25 \mathrm{~g} / \mathrm{kg}$ DM; nd, not detectable by analytical method used (see p. 237).

${ }^{a, b}$ Mean values within a row with unlike superscript letters were significantly different (one-way ANOVA and Tukey's multiple range test; $P>0.05$ ).

${ }^{*}$ For details of diets and procedures, see Table 1 and p. 235.

† Significant $(P<0.05)$ linear increase with increasing dietary threonine level.

$\ddagger$ Significant $(P<0.05)$ linear decrease with increasing dietary threonine level.

these values together with the high $r^{2}$ values provide good evidence that our linear fit represents an acceptable description of our accretion data. Therefore, we believe the present results with Atlantic salmon fry provide clear evidence that Thr utilisation above maintenance (and below the requirement for maintenance + protein accretion) is constant. It can be argued that, if no diminishing return was observed, it may be because Thr intake even at the highest level (93\% of ideal) was lower than the overall needs of salmon fry. However, calculating the overall $\mathrm{Thr}$ requirement from our present data, we obtained $11.4 \mathrm{~g} / \mathrm{kg}$ dry diet or $2.8 \mathrm{~g} / 16 \mathrm{~g} \mathrm{~N}$, two values very similar to our previously published results $(12.1 \mathrm{~g} / \mathrm{kg}$ dry diet or $2.7 \mathrm{~g} / 16 \mathrm{~g} \mathrm{~N}$; Rollin et al. 2003a) and to the highest Thr level tested in the present experiment $(11.75 \mathrm{~g} / \mathrm{kg}$ dry diet or $3 \mathrm{~g} / 16 \mathrm{~g} \mathrm{~N}$ ). In any event, the present results undoubtedly reflect the excellent genetic, age and weight uniformity of salmon fry used in the present experiment.

Very few data on AA maintenance requirements are presently available in the piscine literature (Mambrini \& Kaushik, 1995; Mambrini \& Seudre, 1995; Rodehutscord et al. 1997; Fournier et al. 2002). To our knowledge, no such data are available for fish fry and only one estimation has been published for Thr; this was for rainbow trout (Rodehutscord et al. 1997). It is interesting to compare the estimation of Thr requirement for maintenance obtained in the present study to data already reported in fish as well as in higher vertebrates. The estimation of $\mathrm{Thr}$ maintenance requirement obtained here in salmon fry (about $7 \mathrm{mg} / \mathrm{kg}$ MBW per d) seems much lower than the published data for pigs $(39 \mathrm{mg} /$ $\mathrm{kg}$ MBW per d, Baker et al. 1966; $53 \mathrm{mg} / \mathrm{kg}$ MBW per d,
Fuller et al. 1989), chicks (46 mg/kg MBW per d, Edwards et al. 1997), rats $(54 \mathrm{mg} / \mathrm{kg} \mathrm{MBW}$ per d, Gustafson et al. 1984) and even in $100 \mathrm{~g}$ (average body weight) rainbow trout, i.e. $18.8 \mathrm{mg} / \mathrm{kg} \mathrm{MBW}$ per $\mathrm{d}$ or $17 \%$ of the total $\mathrm{Thr}$ requirement for protein accretion (Rodehutscord et al. 1995a,b, 1997). Atlantic salmon is an ectotherm living in cold water (Elliott, 1991). Compared with homeotherms, this species shows reduced protein growth, synthesis and turnover (Houlihan et al. 1995). This probably explains the lower maintenance AA requirements when compared with homeothermic animals. Moreover, several assumptions can be made to explain the possible lower maintenance Thr requirement of salmon fry compared with $100 \mathrm{~g}$ rainbow trout when expressed as per kg MBW per d. Firstly, Rodehutscord et al. (1995a,b, 1997) estimated the maintenance requirement in rainbow trout through intrapolation of dose-response data to zero growth using an exponential model. However, if their response curve for protein deposition is carefully studied, and if $\mathrm{Thr}$ levels above the total $\mathrm{Thr}$ requirement are eliminated, straight-line fit appears to describe their response curve as well or even better than the exponential model and would certainly have resulted in a much lower estimation of Thr requirement for maintenance in that species. The choice of the model has a substantial effect on the estimate of requirement (Fuller, 1994). Second, the average body weight of rainbow trout used by the German researchers was much higher ( $100 \mathrm{~g} / \mathrm{fish})$ than that considered in the present study on Atlantic salmon fry (approximately $1.5 \mathrm{~g} / \mathrm{fish}$ ). It is possible that AA maintenance needs increase as the fish increase in size, as has been reported for pigs (Fuller, 1994), being greater in growing fish than in 
fry. Thr is a major component of mucosal mucins, which are important constituents of mucus that protect the mucosa, and it is continuously being produced and sloughed into the gut (Wilson et al. 1981; Fuller, 1994), but also over the epidermis (Perry \& Laurent, 1993). Maintenance requirements of Thr may be directly related to the Thr turnover rate in the growing gut, the mucus production of the skin and ultimately to the size of the gut and of the skin. After first feeding, the internal organs of salmonids, including the gut and skin, have been reported to grow faster than the body as a whole (Denton \& Yousef, 1976; Weatherley \& Gill, 1983; Shearer, 1995). This could partly explain a higher Thr maintenance requirement for fry when compared with growers. Further insight is needed on whether Thr maintenance requirement is related to fish size and Thr turnover rate in the growing gut. The influence of mucus production on Thr losses at maintenance, as well as the form of the response of body Thr accretion to dietary Thr supply at low Thr intakes, should also be determined in the future.

With our estimate of the maintenance requirement for absorbed Thr of $7.2 \mathrm{mg} / \mathrm{kg}$ MBW per d (assuming an absorption efficiency of $100 \%$ for Thr; Espe et al. 1992; Espe, 1993), together with the recent estimate (Rollin et al. 2003a) of the total requirement for digestible $\mathrm{Thr}$ of $1.21 \%$ of diet $(54 \mathrm{mg} /$ $\mathrm{kg}$ MBW per d), it can be calculated that the Thr maintenance requirement represents $13.4 \%$ of the total digestible Thr need for Atlantic salmon fry during this early growth phase.

The loss of body N, observed in animals on a diet devoid of one IAA, varied with the type of AA omitted (D'Mello, 2003c). In the rat, Said \& Hegsted (1970) and Heger \& Frydrych (1985) identified Thr-free and isoleucine-free diets together with a diet free of sulfur AA as those that caused the loss of body $\mathrm{N}$ comparable to a PF diet. In the present experiment, the whole-body Thr loss observed with the LP diet devoid of Thr was also similar $(P>0.05)$ to the Thr loss obtained with the PF diet. It seems that the extent of $\mathrm{N}$ loss due to the severe AA deficiency depends on the order of limitation of endogenous AA (Heger \& Frydrych, 1985). The importance of Thr in maintenance has been reported in a number of studies in rats, pigs, cats and dogs (Yokogoshi \& Yoshida, 1976; Fuller et al. 1989; Hendricks et al. 1996; Hendricks, 2003), and when supplementated to a PF diet it has been demonstrated to have a significant N-sparing effect in the rat (Yoshida \& Moritoki, 1974). Furthemore, our data show that, even in presence of large amounts of the other IAA, the Thr gain is strictly related to Thr intake. Further studies will have to highlight if: (1) Thr is one of the first-limiting AA of endogenous origin under maintenance conditions in salmon fry; (2) some body proteolysis occurs in fry fed diets devoid of Thr to ensure compensatory proteosynthesis in the presence or absence of large amounts of the other IAA.

The exact value for the efficiency term is crucial to the application of the factorial method for the estimation of AA requirements (Fuller, 1994). In the present study, the efficiency of recovery of ingested Thr above maintenance in whole-body protein was 76 (SE 3.4) \% and seemed constant at all levels of Thr intake between 1 and $93 \%$ of its requirement for optimum protein deposition. For instance, with Thr at $83 \%$ of its ideal level, $63 \%(8.2 \mathrm{mg} / \mathrm{fish})$ of the $\mathrm{Thr}$ intake $(13 \mathrm{mg} /$ fish $)$ was recovered in whole-body protein (Table 5). Of the $37 \%$ not recovered, $13.4 \%$ can be assigned to the maintenance need, and the remaining $23.6 \%$ can be assigned to oxidation loss. This last value corresponds well with the $24 \%$ loss (100 minus $76 \%$ ) estimated from regression (Fig. 1 (a)). Thus, Thr utilisation above maintenance showed no evidence of diminishing returns (i.e. declining efficiency) as its level in the diet was increased. This finding of constant efficiency (above maintenance) agrees well with previous work in Atlantic salmon fry, in which constant utilisation (above maintenance) was observed for lysine below the requirement for maintenance plus protein accretion (70\%, Rollin, 1999; $71 \%$, Hauler \& Carter, 2001b). Unfortunately, there is little published information on fish with which to compare these estimates. Recently, Encarnação et al. (2004) reported in rainbow trout that, at marginally deficient lysine intake levels, efficiency of lysine utilisation for body protein deposition (lysine retained/lysine intake) was contained between 65 and $75 \%$ for the high-energy diet (20 MJ digestible energy $/ \mathrm{kg}$ ), these values being in the range of our estimates. Some other estimates of AA utilisation efficiency have also been reported in fish larvae and post-larvae. In post-larval Senegal sole (Solea senegalensis), Rønnestad et al. $(2000,2001 a, b)$ reported assimilation efficiency (label AA retained/total label AA fed) of 87,82 and $89 \%$ for lysine, arginine and methionine, respectively. High assimilation of methionine (85-90\%) was also found in larval stages of striped bass (Morone saxatilis) and Walleye (Stizostedion vitreum; Rust, 1995). Estimating a metabolic budget for lysine in fasting herring (Clupea harengus) larvae, Conceição et al. (2002) reported a $70 \%$ utilisation efficiency in first-feeding larvae and $63 \%$ in 47-d-old (premetamorphosis) larvae. However, since these values have been obtained with larval fish, which have been reported to be morphologically and functionally incomplete (Fyhn, 1989), and/or with completely different methodologies (tube-feeding using ${ }^{14} \mathrm{C}$-labelled AA or proteins; Rust et al. 1993; Rønnestad et al. 2001a,b), it makes difficult direct comparisons with the present results (number of fish tested, level of intake, composition of the diets used, etc).

Paradoxically, from a methodological point of view, most of the data available on mammals and birds are easier to compare with our own data. Indeed, in the present study, we draw our inspiration from methodologies mainly applied to singlestomached animals over several years (D'Mello, 1982, 2003a,b). Most chick work (Baker, 1991; Baker et al. 1996; Edwards et al. 1997, 1999) has reported a constant AA utilisation efficiency (above maintenance): Thr (82\%), valine $(73 \%)$, lysine $(80 \%)$ and isoleucine $(61 \%)$. Likewise, similar studies involving graded dosing in pigs also resulted in efficiency estimates above maintenance that were constant at all levels of intake of the limiting AA: $74 \%$ (Bikker, 1994) to $86 \%$ (Batterham et al. 1990; Adeola, 1995) for lysine, $72 \%$ (Chung \& Baker, 1992) for methionine and only $60 \%$ (Adeola, 1995) for Thr, considerably less than our present estimate for salmon fry and also that reported for chicks (Edwards et al. 1999). Batterham (1994) evaluated efficiencies for retaining ileal digestible AA from soyabean meal in growing pigs and reported efficiencies (including maintenance costs) of $75 \%$ for lysine, $64 \%$ for Thr, $45 \%$ for methionine and $38 \%$ for tryptophan. From the studies that have been reported in single-stomached animals, it seems that individual IAA differ in the efficiency with 
which absorbed AA are retained in whole-body protein. Our estimate of Thr utilisation above maintenance in Atlantic salmon fry is similar to that observed for lysine in similar experimental conditions (Rollin, 1999). This has also been reported in chicks (Baker, 1991; Edwards et al. 1997), but work in pigs and rats has suggested that lysine is retained more efficiently than Thr (Adeola, 1995; Gahl et al. 1996). However, it is difficult to make an objective comparison between values reported in different studies and, moreover, in different animal species, different dietary models, etc. For instance, energy concentration and lipid levels in pig and poultry diets are much lower than in salmonid diets. Furthermore, regulation of AA utilisation in fish may be different from pigs and poultry (Encarnação et al. 2004), in which AA catabolism appears to play a much smaller role in supplying energy than carbohydrates and lipids. Therefore, caution is warranted when transposing concepts or when comparing AA utilisation efficiency values in other single-stomached animals with fish species.

It has been widely documented that a reduction in feed intake may be regarded as the primary factor responsible for depressed growth in rats, chickens, kittens and beagle dogs fed diets deficient or limiting in Thr (Titchenal et al. 1980; Burns \& Millner, 1982; Cieslak \& Benevenga, 1984; Webel et al. 1996). This was also observed in the present study with Atlantic salmon fry as well as in other studies with chum salmon (Oncorhynchus keta; Akiyama et al. 1985), rainbow trout (Rodehutscord et al. 1995a,b), common carp (Cyprinus carpio; Nose, 1979) and Catla catla (Ravi \& Devaraj, 1991). However, in other studies carried out to assess the overall Thr requirement of the channel catfish (Ictalurus punctatus; Wilson et al. 1978), milkfish (Chanos chanos; Borlongan, 1991), red drum (Sciaenops ocellatus; Boren \& Gatlin, 1995), hybrid striped bass (Morone chrysops $q \times$ M. saxatilis $0^{7}$; Keembiyehetty \& Gatlin, 1997) or European sea bass (Dicentrachus labrax; Tibaldi \& Tulli, 1999), the dietary deficiency of Thr was coupled with only minor or no effect on feed intake. To date, we do not have any ready explanation for these discrepancies. However, at least in some studies, it could be related to an overestimation of feed intake (Hauler \& Carter, 2001a).

The Thr and protein accretion data of the present experiment point to at least six important conclusions: (1) efficiency of utilising (retaining) absorbed $\mathrm{Thr}$ above maintenance was $76 \pm 3 \%$; (2) efficiency of utilising absorbed Thr above maintenance was constant at Thr intakes between 1 and $93 \%$ of the (ideal) Thr level required for optimal protein deposition; (3) Thr concentration in the whole-body protein accreted was the same at all levels of Thr intake; (4) zero protein accretion resulted in negative Thr accretion, suggesting a higher maintenance $\mathrm{Thr}$ requirement for zero $\mathrm{Thr}$ accretion than for zero protein gain; (5) the maintenance need for Thr represented $13.4 \%$ of the total need (maintenance + accretion) for Thr; (6) the wholebody Thr loss observed with the LP diet devoid of Thr was similar to the Thr loss obtained with the PF diet.

\section{Acknowledgements}

The authors gratefully acknowledge Marc Michotte for his expert technical assistance, Diane Dekeyser for preparative work for AA analysis and Vivien Bednarski for proofreading.

\section{References}

Adeola O (1995) Dietary lysine and threonine utilization by young pigs: efficiency for carcass growth. Can J Anim Sci 75, 445-452.

Akiyama T, Arai S \& Murai T (1985) Threonine, histidine and lysine requirement of chum salmon fry. Bul Jap Soc Sci Fish 51, 635-639.

Allen GL, Johnson RJ, Stone DAJ \& Frances J (1998) Estimating digestible protein and lysine requirements of silver perch. In Fish Meal Replacement in Aquaculture Feed for Silver Perch, pp. 199-214 [GL Allen and SJ Rowlands, editors]. Australia: Report 120-03, Fisheries Research and Development Corporation Deakin.

Association of Official Analytical Chemists (1995) Official Methods of Analysis, 16th ed. Arlington, VA: AOAC.

Baker DH (1991) Partitioning of nutrient for growth and other metabolic functions: efficiency and priority considerations. Poultry Sci 70, 1797-1805.

Baker DH (2003) Ideal amino acid patterns for broiler chicks. In Amino Acid in Animal Nutrition, 2nd ed., pp. 223-235 [JPF D'Mello, editor]. Wallingford, UK: CAB International.

Baker DH, Becker DE, Norton HW, Jensen AH \& Harmon BG (1966) Quantitative evaluation of the threonine, isoleucine, valine and phenylalanine needs of adult swine for maintenance. J Nutr $\mathbf{8 8}$, 391-396.

Baker DH, Fernandez SR, Parsons CM, Edwards HM III, Emmert JL \& Webel DM (1996) Maintenance requirement for valine and efficiency of its use above maintenance for accretion of whole-body valine and protein in young chicks. $J$ Nutr 126, 1844-1851.

Ballèvre O, Cadenhead A, Calder AG, Rees WD, Lobley GE, Fuller MF \& Garlick PJ (1990) Quantitative partition of threonine oxidation in pigs: effect of dietary threonine. Am J Physiol 259, E483-E491.

Batterham ES (1994) Ileal digestibilities of amino acids in feedstuffs. In Amino Acids in Farm Animal Nutrition, pp. 113-131 [JPF D'Mello, editor]. Wallingford, Oxon: CAB International.

Batterham ES, Anderson LM, Baigent DR \& White E (1990) Utilization of ideal digestible amino acids by growing pigs: effect of dietary lysine concentration on efficiency of lysine retention. Br J Nutr 64, 81-94.

Bikker P (1994) Protein and lipid accretion in body components of growing pigs. PhD Thesis, , Wageningen Agricultural University.

Bird MI \& Nunn PB (1983) Metabolic homeostasis of L-threonine in the normally-fed rat. Importance of liver threonine dehydrogenase activity. Biochem J 214, 687-694.

Boren RS \& Gatlin DM III (1995) Dietary threonine requirement of juvenile red drum (Sciaenops ocellatus). J World Aquac Soc 26, $279-283$.

Borlongan IG (1991) Quantitative arginine and threonine requirements of milkfish (Chanos chanos) juveniles. Aquaculture $\mathbf{9 3}$ $312-322$.

Burns RA \& Millner JA (1982) Threonine, tryptophan and histidine requirements of immature beagle dogs. J Nutr 112, 447-452.

Campbell RG, Taverner MR \& Curic DM (1984) Effect of feeding level and dietary protein content on the growth, body composition and rate of protein deposition in pigs growing from 45 to $90 \mathrm{~kg}$. Anim Prod 38, 233-240.

Campbell RG, Taverner MR \& Curic DM (1985) The influence of feeding level on the protein requirement of pigs between 20 and $45 \mathrm{~kg}$ live weight. Anim Prod 40, 489-496.

Chung TK \& Baker DH (1992) Efficiency of dietary methionine utilization by young pigs. J Nutr 122, 1862-1869.

Cieslak DG \& Benevenga NJ (1984) The effect of amino acid excess on utilization by the rat of the limiting amino acids lysine and threonine at equalized food intakes. J Nutr 114, 1878-1883.

Conceição LE, Rønnestad I \& Tonheim SK (2002) Metabolic budgets for lysine and glutamate in unfed herring (Clupea harengus) larvae. Aquaculture 201, 161-175. 
Cowey CB (1994) Amino acid requirements of fish: a critical appraisal of present values. Aquaculture 124, 1-11.

Cowey CB (1995) Protein and amino acid requirements: a critique of methods. J Appl Ichthyol 11, 199-204.

Cowey CB \& Luquet P (1983) Physiological basis of protein requirements of fishes. Critical analysis of allowances. In Protein Metabolism and Nutrition, vol. 1, pp. 364-384 [M Arnal, R Pion and D Bonin, editors]. Paris: INRA.

Dabrowski K \& Guderley H (2002) Intermediary metabolism. In Fish Nutrition, 3rd ed. pp. 310-367 [JE Halver and RW Hardy, editors]. San Diego, CA: Academic Press.

Dabrowski K, Lee KJ \& Rinchard J (2003) The smallest vertebrate, telesot fish, can utilize synthetic dipeptide-based diets. J Nutr 133, 4225-4229.

Denton JD \& Yousef MK (1976) Body composition and organ weights of rainbow trout, Salmo gairdneri. J Fish Biol 8, 489-499.

D'Mello JPF (1982) A comparison of two empirical methods of determining amino acid requirements. World Poult Sci J 38, 114-119.

D'Mello JPF (1983) Amino acid requirements of the turkey poult. In Proceedings of the 4th European Symposium on Poultry Nutrition, pp. 66-73 [M Larbier, editor]. Tours, France: World's Poultry Science Association.

D'Mello JPF (1994a) Responses of growing poultry to amino acids. In Amino Acids in Farm Animal Nutrition, pp. 205-243 [JPF D'Mello, editor]. Wallingford, UK: CAB International.

D'Mello JPF (1994b) Amino acid imbalances, antagonisms and toxicities. In Amino Acids in Farm Animal Nutrition, pp. 63-97 [JPF D'Mello, editor]. Wallingford, UK: CAB International.

D'Mello JPF (2003a) Responses of growing poultry to amino acids. In Amino Acids in Animal Nutrition, 2nd ed., pp. 223-263 [JPF D'Mello, editor]. Wallingford, UK: CAB International.

D'Mello JPF (2003b) Adverse effects of amino acids. In Amino Acids in Animal Nutrition, 2nd ed., pp. 125-142 [JPF D'Mello, editor]. Wallingford, UK: CAB International.

D'Mello JPF (2003c) Amino acids as multifunctional molecules. In Amino Acids in Animal Nutrition, 2nd ed., pp. 1-14 [JPF D'Mello, editor]. Wallingford, UK: CAB International.

Draper NR \& Smith H (1981) Applied Regression Analysis, 2nd ed. New York: John Wiley and Sons.

Dunkin AC, Black JL \& James KJ (1986) Nitrogen balance in relation to energy intake in entire male pigs weighing $75 \mathrm{~kg}$. Br J Nutr $\mathbf{5 5}$, 201-207.

Durbin T \& Watson GS (1951) Testing for serial correlation in least square regression II. Biometrica 38, 159-178.

Edwards HM III, Baker DH, Fernandez SR \& Parsons CM (1997) Maintenance threonine requirement and efficiency of its use for accretion of whole-body threonine and protein in young chicks. Br J Nutr 78, 111-119.

Edwards HM III, Fernandez SR \& Baker DH (1999) Maintenance lysine requirement and efficiency of using for accretion of whole-body lysine and protein in young chicks. Poultry Sci 78, $1412-1417$

Elliott JM (1991) Tolerance and resistance to thermal stress in juvenile Atlantic salmon, Salmo salar. Freshwat Biol 25, 61-70.

Encarnação P, de Lange C, Rodehutscord M, Hoehler D, Bureau W \& Bureau DP (2004) Diet digestible energy content affects lysine utilization, but not dietary lysine requirements of rainbow trout (Oncorhynchus mykiss) for maximum growth. Aquaculture 235, 569-586.

Espe M (1993) Studies on the utilization of pre-digested fish proteins in Atlantic salmon (Salmo salar). PhD Thesis, Institute of Nutrition, Directorate of Fisheries and University of Bergen.

Espe M, Haaland H \& Njaa LR (1992) Substitution of fish silage protein and a free amino acid mixture for fish meal protein in a chicken diet. J Sci Food Agric 58, 315-320.

Fisher C, Morris TR \& Jennings RC (1973) A model for the description and prediction of the response of laying hens to amino acid intake. Br Poult Sci 14, 469-484.
Fournier V, Gouillou-Coustans MF, Métailler R, Vachot C, Guedes MJ, Tulli F, Oliva-Teles A, Tibaldi E \& Kaushik SJ (2002) Protein and arginine requirements for maintenance and nitrogen gain in four teleosts. Br J Nutr 87, 459-469.

Fuller MF (1994) Amino acid requirements for maintenance, body protein accretion and reproduction. In Amino Acids in Farm Animal Nutrition, pp. 155-184 [JPF D'Mello, editor]. Wallingford, Oxon: CAB International.

Fuller MF \& Garthwaite P (1993) The form of response of body protein accretion to dietary amino acid supply. J Nutr 123, 957-963.

Fuller MF, McWilliam R, Wang TC \& Giles LR (1989) The optimum dietary amino acid pattern for growing pigs. 2. Requirements for maintenance and for tissue protein accretion. Br J Nutr 62, 255-267.

Fyhn HJ (1989) First feeding of marine fish larvae: are free amino acids the source of energy?" Aquaculture 80, 111-120.

Gahl M, Finke MD, Crenshaw TD \& Benevenga NJ (1991) Use of a four parameter logistic equation to evaluate the response of growing rats to ten levels of each indispensable amino acid. J Nutr 121, $1720-1729$.

Gahl M, Finke MD, Crenshaw TD \& Benevenga NJ (1996) Efficiency of lysine or threonine retention in growing rats fed diets limiting in either lysine or threonine. J Nutr 126, 3090-3099.

Gous RM (1980) An improved method for measuring the response of broiler chickens to increasing dietary concentrations of an amino acid. In Proceedings of the 6th European Poultry Conference, vol. III, pp. 32-39. Hamburg: World's Poultry Science Association.

Gustafson JM, Dodds SJ, Rudquist J, Kelley J, Ayers S \& Mercer LP (1984) Food intake and weight gain responses to graded amino acid deficiencies in rats. Nutr Rep Int 30, 1019-1025.

Hara TJ, Macdonald S, Evans RE, Marui T \& Arai S (1984) Morpholine, bile acids and skin mucus as possible chemical cues in salmonid homing: electrophysiological re-evaluation. In Mechanisms of Migration in Fishes, pp. 363-378 [JD McCleave, GP Arnold, JJ Dodson and WH Neill, editors]. New York: Plenum.

Hauler RC \& Carter CG (2001a) Reevaluation of the quantitative dietary lysine requirements of fish. Rev Fish Sci 9, 133-163.

Hauler RC \& Carter CG (2001b) Lysine deposition responds linearly to marginal lysine intake in Atlantic salmon (Salmo salar L.) parr. Aquac Res 32, Suppl. 1, 147-156.

Heger J \& Frydrych Z (1985) Efficiency of utilisation of essential amino acids in growing rats at different levels on intake. $\mathrm{Br} J$ Nutr 54, 499-508.

Hendricks WH (2003) Canine and feline amino acid requirements for different physiological functions. In Amino acids in Animal Nutrition, 2nd ed., pp. 411-426 [JPF D'Mello, editor]. Wallingford, UK: CAB International.

Hendricks WH, Moughan PJ \& Tarttelin MF (1996) Gut endogenous nitrogen and amino acid excretions in adult domestic cats using a protein-free diet or an enzymatically hydrolyzed casein-based diet. J Nutr 126, 955-962.

Houlihan DF, Carter CG \& McCarty ID (1995) Protein synthesis in fish. In Biochemistry and Molecular Biology of Fishes, vol. 4, Metabolic Biochemistry, pp. 191-220 [PW Hochachka and TP Mommsen, editors]. Amsterdam: Elsevier.

Keembiyehetty CN \& Gatlin DM III (1997) Dietary threonine requirement of juvenile hybrid striped bass (Morone chrysops $q$ x M. saxatilis $\sigma^{7}$ ). Aquaculture Nutrition 3, 217-221.

Kidd MT, Kerr BJ \& Anthony NB (1997) Dietary interaction between lysine and threonine in broilers. Poultry Sci 76, 608-614.

Mambrini M (1996) Besoins en acides aminés des poissons: détermination des besoins en acides amines soufrés pour l'entretien et l'accrétion protéique (Amino acid requirements in fish: determination of sulfur amino acids requirements for maintenance and for protein accretion). In Journées Nutrition des Poissons INRAIFREMER 21-22.02.96, pp. 17-20. Saint-Pée sur Nivelle: INRA, Unité mixte INRA-IFREMER de Nutrition des Poissons. 
Mambrini M \& Kaushik SJ (1994) Partial replacement of dietary protein nitrogen with dispensable amino acids in diets of Nile tilapia Oreochromis niloticus. Comp Biochem Physiol 109A 469-477.

Mambrini M \& Kaushik SJ (1995) Effect of temperature on sulfur amino acid requirements for maintenance and growth of juvenile rainbow trout. In Protein Metabolism and Nutrition, pp. 117-122 [AF Nunes, AV Portugal, JP Costa and JR Ribeiro, editors]. Oeiras, Portugal: INIA.

Mambrini M \& Seudre L (1995) Sulfur amino acid requirements for maintenance and growth of juvenile rainbow trout. Reprod Nutr Dév 35, 603-604.

Mercer LP (1982) The quantitative nutrient-response relationship. J Nutr 112, 560-566.

Morris TR, Al-Azzawi K, Gous RM \& Jackson GL (1987) Effects of protein concentration on responses to dietary lysine by chicks. Br Poult Sci 33, 185-195.

National Research Council (1993) Nutrients Requirements of Fish. Washington, DC: National Academy Press.

Nose T (1979) Summary report on the requirement of essential amino acids for carp. In Proceedings of the World Symposium on Finfish Nutrition and Finfish Technology, vol. 1, pp. 145-156 [JE Halver and JE Tiews, editors]. Berlin: Heenemann.

Ooghe W (1983) On the influence of hydrogen peroxide on the amino acid composition of foodstuffs. In Proceedings of the Second European Conference on Food Chemistry, Euro Food Chem II, pp. 315-321. Rome: The Federation of European Chemical Societies, Working Party on Food Chemistry and the Italian Society for Food Science.

Pack M, Hoehler D \& Lemme A (2003) Economic assessment of amino acid responses in growing poultry. In Amino Acids in Farm Animal Nutrition, 2nd ed., pp. 459-483 [JPF D'Mello, editor]. Wallingford, UK: CAB International.

Perry SF \& Laurent P (1993) Environmental effects of fish gill structure and function. In Fish Ecophysiology, pp. 231-264 [JC Rankin and FB Jensen, editors]. London: Chapman \& Hall.

Ravi J \& Devaraj KV (1991) Quantitative essential amino acid requirements for growth of catla, Catla catla (Hamilton). Aquaculture 96, 281-291.

Rodehutscord M, Becker A, Pack M \& Pfeffer E (1997) Response of rainbow trout (Oncorhynchus mykiss) to supplements of individual essential amino acids in a semipurified diet, including an estimate of the maintenance requirement for essential amino acids. J Nutr 127, 1166-1175.

Rodehutscord M, Borchert F, Gregus Z, Pack M \& Pfeffer E (2002) Availability and utilization of free lysine in rainbow trout (Oncorhynchus mykiss). I. Effect of dietary crude protein level. Aquaculture 187, 163-176.

Rodehutscord M, Jacobs S, Pack M \& Pfeffer E (1995a) Response of rainbow trout (Oncorhynchus mykiss) growing from 50 to $150 \mathrm{~g}$ to supplements of DL-methionine in a semipurified diet containing low or high levels of cystine. J Nutr 125, 964-969.

Rodehutscord M, Jacobs S, Pack M \& Pfeffer E (1995b) Response of rainbow trout (Oncorhynchus mykiss) growing from 50 to $170 \mathrm{~g}$ to supplements of either L-arginine or L-threonine in a semipurified diet. J Nutr 125, 970-975.

Rodehutscord M \& Pack M (1999) Estimates of essential amino acid requirements from dose-response studies with rainbow trout and broiler chicken: effect of mathematical model. Arch Anim Nutr 52, 223-244.

Rollin X (1999) Etude critique des besoins en acides aminés indispensables de l'alevin de saumon atlantique (Salmo salar L.) (Critical study of the indispensable amino acids requirements in Atlantic salmon (Salmo salar L.) fry). PhD Thesis, Université catholique de Louvain.

Rollin X, Mambrini M, Abboudi T, Larondelle Y \& Kaushik S (2003a) The optimum dietary indispensable amino acid pattern for growing Atlantic salmon (Salmo salar) fry. Br J Nutr 90, 865-876.
Rollin X, Peng J, Pham D, Ackman RG \& Larondelle Y (2003b) The effects of dietary lipid and strain difference on polyunsaturated fatty acid composition and conversion in anadromous and landlocked salmon (Salmo salar L.) parr. Comp Biochem Physiol 134B 349-366.

Rønnestad I, Conceição LE, Aragão C \& Dinis MT (2000) Free amino acids are absorbed faster and assimilated more efficiently than protein in postlarval Senegal sole. J Nutr 130, 2809-2812.

Rønnestad I, Conceição LE, Aragão C \& Dinis MT (2001a) Assimilation and catabolism of dispensable and indispensable free amino acids in post-larval Senegal sole (Solea senegalensis). Comp Biochem Physiol 130C, 461-466.

Rønnestad I, Rojas-García CR, Tonheim SK \& Conceição LE (2001b) In vivo studies of digestion and nutrient assimilation in marine fish larvae. Aquaculture 201, 161-175.

Rust MB (1995) Quantitative aspects of nutrient assimilation in six species of fish larvae. PhD Thesis, Seattle: University of Washington, School of Fisheries.

Rust MB, Hardy RW \& Stickney RR (1993) A new method for forcefeeding larval fish. Aquaculture 116, 341-352.

Said AK \& Hegsted DM (1970) Response of adult rats to low dietary levels of essential amino acids. J Nutr 100, 1363-1375.

Saldana CI, Knabe DA, Owen KQ, Burgoon KG \& Gregg EJ (1994) Digestible threonine requirements of starter and finisher pigs. J Anim Sci 72, 144-150.

Shearer K (1995) The use of factorial modeling to determine the dietary requirements for essential elements in fishes. Aquaculture $\mathbf{1 3 3}$, $57-72$.

Sokal RR \& Rohlf FJ (1995) Biometry: the Principles and Practice of Statistics in Biological Research, 3rd ed. New York, NY: Freeman and Company.

Tacon AGJ \& Cowey CB (1985) Protein and amino acid requirements. In Fish Energetics: New Perspectives, pp. 155-183 [P Tytler and P Calow, editors]. Baltimore, MD: The Johns Hopkins University Press.

Tibaldi E \& Tulli F (1999) Dietary threonine requirement of juvenile European sea bass (Dicentrarchus labrax). Aquaculture 175, 155-166.

Titchenal CA, Rogers QR, Indrieri RJ \& Morris JG (1980) Threonine imbalance, deficiency and neurologic dysfunction in the kitten. J Nutr 110, 2444-2459.

Weatherley AH \& Gill HS (1983) Relative growth of tissues at different somatic growth rates in rainbow trout, Salmo gairdneri Richardson. J Fish Biol 22, 43-60.

Webel DM, Fernandez SR, Parson CM \& Baker DH (1996) Threonine requirement of broiler chickens during the period 3 to 6 and 6 to 8 weeks posthatching. Poultry Sci 75, 1253-1257.

Wilson RP (2002) Amino acids and proteins. In Fish Nutrition, 3rd ed., pp. 143-179 [JE Halver, editor]. San Diego, CA: Academic Press.

Wilson RP (2003) Amino acid requirements of finfish and crustaceans. In Amino Acids in Animal Nutrition, 2nd ed., pp. 427-447 [JPF D’Mello, editor]. Wallingford, UK: CAB International.

Wilson RP, Allen OW, Robinson EH \& Poe WE (1978) Tryptophan and threonine requirements of fingerling channel catfish. $J$ Nutr 108, 1595-1599.

Wilson RP, Poe WE \& Robinson EH (1981) Apparent and true availability of amino acids from common feed ingredients for channel catfish. J Nutr 111, 923-929.

Yokogoshi H \& Yoshida A (1976) Some factors affecting the nitrogen sparing action of methionine and threonine in rats fed a protein free diet. J Nutr 106, 48-57.

Yoshida A \& Moritoki K (1974) Nitrogen sparing action of methionine and threonine in rats receiving a protein free diet. Nutr Rep Int 9, $159-168$. 